\title{
Bridging the Gap in Learning Differences Among Biology Students Using 4 Mode Application Techniques
}

Dr Queendaline Ibenegbu Obiajulu

University of Nigeria Nsukka

Dr Chidinma Blessing Ugwu

University of Nigeria Nsukka

Dr Christopher Ifeanyi lbenegbu ( $\nabla$ christopher.ibenegbu@unn.edu.ng )

University of Nigeria Nsukka https://orcid.org/0000-0002-2394-3787

Helen Onyinye Muojekwu

University of Nigeria Nsukka

Dr Nonye Odionye

University of Nigeria Nsukka

Dr Anthonia Ngozi Ngwu

University of Nigeria Nsukka

Okafor Blessing ljeoma

Federal College of Education (Tech.) Umunze

Nwankwo Amaka Loretta

University of Nigeria Nsukka

Dr Obiageli Loretta Aniaku

University of Nigeria Nsukka

Dr Regina ljeamasi Enebechi

Institute of Ecumenical Education, Thinkers Corner Enugu

Chukwunta Regina Ugochi

University of Nigeria Nsukka

\section{Research Article}

Keywords: 4MAT, learning styles, Biology, Gender, Techniques

Posted Date: December 17th, 2021

DOI: https://doi.org/10.21203/rs.3.rs-1179251/v1

License: @ (i) This work is licensed under a Creative Commons Attribution 4.0 International License. Read Full License 


\section{Abstract}

This study is on bridging the gap in learning differences among biology students using 4MAT Application Techniques. We carried out the study in Abakaliki, Nigeria. We adopted a quasi-experimental design for the study. We used 138 SS-II students from two schools. Two hypotheses were tested. We analyzed the data using descriptive statistics and Hierarchical Analysis of covariance (ANCOVA). The results showed that there was a significant main effect of instructional method on students' achievement in biology $F(7,121)=$ $12.654, p=.000$, partial $\eta 2=.39$; there was no significant main effect of gender on students' achievement in biology $F(1,121)=1.240$, $p=.268$, partial $\eta 2=.004$. We highlighted the educational implications of the findings and the recommendations. We also made some limitations of the study and suggestions for further studies.

\section{Introduction}

Understanding how students learn is one of the most important tasks a teacher can undertake in the classroom, and another is learning how to provide opportunities for learning with these identified learning preferences. Teachers often use their preferred learning style as their main mode of teaching and students do not share those same preferences then learning can be very difficult and stressful. Therefore, teachers need to understand the differences in students' learning preferences in other to maximize students learning potentials.

Learning style is an individual's unique way of perceiving and processing information. According to Reynolds (2007), learning style is an individual's natural or habitual pattern of acquiring and processing information in a learning situation. The notion of learning style and its implications in education is not new in the education system (Reynolds, 2007). Learning style specifically deals with each individual's characteristic style of acquiring knowledge (Byrne, 2002). Learning style is also an individual's special way of understanding and applying information gathered during the teaching and learning process. Dunn and Griggs (2000) stated that serious consideration is rarely paid to the existence of differences in learning styles and their impact on teaching and learning, with few attempts being made to systematically incorporate learning styles into teaching. Ubah (2012) reported that knowledge of the existing learning styles among students could increase their academic success. Reynolds (2007) proposed that matching learning styles and instructional methods could lead to improved learning. More importantly, Rochford (2004) posited that students' knowledge of their learning style preferences could improve students' rate of retention of information. Students preferentially take in and process information in different ways: by seeing and hearing, reflecting and acting, reasoning logically and intuitively; and analyzing and visualizing. This shows that every student has a particular learning style.

In the classroom, students come in with their different learning styles and all the dominant learning styles needs to be addressed during the learning process (Merrill, 1993). When teachers are considering the design of a learning process for the active learning classroom environment, there is a need for them to be aware of the impact of learning styles of students to create an enabling environment for learning to take place. Brown (2003) stated that if the instructional design matches students' learning style preferences, it could have a positive impact on students' achievement. Besides, Roy (2007) stated that recognizing students' learning styles could help teachers to develop course structures that will provide a better fit between instructional goals and students' 'learning style preferences. The importance of recognizing students learning styles in the classroom learning environment can be highlighted by stating that the teacher emphasizes intuition, feeling, sensing, and imagination, in addition to traditional skills of analysis, reason and sequential problem-solving. The teacher designs instructional methods to connect with different learning styles, using various combinations of experience, reflection, conceptualization, and experimentation. Finally, the teacher employs a variety of assessment techniques, focusing on each of the different learning styles and the development of the whole brain capacity (Brown, 2003).

Bielefeldt (2006) conducted a study on an analysis of right-and left-brain thinkers and certain styles of learning analyzed right-and left-brain thinkers and certain styles of learning (specifically visual, auditory, or kinesthetic) in college-level adult learners. Bielefeldt found out that students have one dominant learning style, and use the other learning styles only as supplements, other students use different styles in different circumstances. There appears to be no right combination. Individuals learn in several ways and no two individuals learn in barely an equivalent method. The analysis supports the idea that the majority of academics teach the method they learn (Stitt-Gohdes, 2001). However, as a result of most students having completely different learning styles, teachers should acknowledge these variations and be ready to adapt they are approach and educational vogue. The theories of brain-based learning and multi-intelligence support the concept that teachers should expand what they are teaching to accommodate the student's learning 
styles. Research-based evidence from the study will be used to encourage instructors to develop and use appropriate styles of teaching to enhance their student's educational experience (Bielefeldt, 2006).

Oflaz studied the effect of right and left brain dominance in language learning. Oflaz (2011) noted that brain dominance has a great impact on the learning process. Therefore, being aware of the brain dominance of scholars is very important. To illustrate the importance of whole-brain functioning, Campbell (2008) remarked on how the human mind forms its notion by mixing up its nature with the nature of things around them. For example, when scientists engage in explicit theory development, they observe and use logical reasoning. However, during the discovering phase that must precede the definitive process of creating a new theory, they often use illogical reasoning which reflects their own subtle biases. The reality is that individuals approach learning with the whole mind, intuition, belief and subjectivity intact.

The above line of thought on the knowledge of learning style led to research by Bernice McCarthy in 1972 about the best way to teach learners in a classroom. This brought about the development of the Four Mode Application Techniques (4MAT). 4MAT is an instructional model that provides a systematic approach to organizing and delivering instructions in a manner that addresses the learning styles and hemispheric preferences of students. 4MAT is an eight-step instructional model that capitalizes on individual learning styles and brain dominance processing preferences. Inherent in the 4MAT are two major premises: one is that people have major learning style and hemispheric (right mode and left mode) processing preferences; secondly, teachers should design and use multiple instructional strategies in a systematic framework to teach to these preferences in other to improve teaching and learning.

In the 4MAT lesson, there is more interactive exchange of information than just giving formation; there is a greater appreciation for diversity as a positive outcome to enhance learning and there is a deeper sense of responsibility for the student during the learning process. The 4MAT is a conceptual framework of teaching and learning that is grounded in the works of John Dewey (experiential learning), Carl Jung (theory of individualization), and, most directly, David Kolb (experiential learning theory) (McCarthy 1987). 4MAT identifies four interrelated learning styles based on how individuals perceive and process new information. Its premise is that individuals learn primarily in one of the four different, but complementary ways based on how they perceive and process information (McCarthy \& McCarthy, 2006). McCarthy identified these four learning styles as Imaginative Learners (Type One Learners); Analytic Learners (Type Two Learners); Common Sense Learners (Type Three Learners); and Dynamic Learners (Type Four Learners), based on Kolb's experiential learning theory thus, divergent, assimilative, convergent and accommodative learning style respectively.

They benefit from opportunities to find meaning in what they are learning and they enjoy discussing their beliefs, feelings, and opinions with others. The type I learners are reflective, learn primarily through dialogue and are skilled at perspective-taking and are sensitive to the needs of others. Analytic Learners approach learning in a logical, organized manner by examining details and specifics. Analytic Learners enjoy reflecting on new ideas and connecting new learning to other information they know to be true. The type 2 learners are logical, enjoy formulating theories and models, strive for precision, and prefer teachers that do so as well. Dynamic Learners are active learners, enjoy taking risks and learn primarily through self-discovery. These learners like to connect their learning to things that matter in their lives. They enjoy synthesizing information and applying their learning in new ways. Dynamic learners prefer doing and feeling things, they seek hidden possibilities, they explore learning by trial and error, and they engage in selfdiscovery (McCarthy, 1987).

These four types of learners would learn best if they were taught how to learn like each other at the same time in other to make learning successful, that is the type one learner has to learn how type two, three, and four learners learn. The teachers have to travel the 4MAT cycle with a spin to engage all the learners in the activities of the four diverse learners. The use of the 4MAT teaching model has been supported by research in elementary and secondary and more recently in higher education classrooms (Wilkerson \& White, 1988; Blair \& Judah, 1990). 4MAT also integrates learning style with brain-based processing strategies and provides a systematic model of planning instruction, which assumes that individuals learn in different but, identifiable ways and that engagement with a variety of diverse learning activities result in higher levels of motivation and performance. 4MAT model moves beyond enhancing students' self-awareness of their learning strengths and weaknesses, to a framework students can use to adapt to the variety of teaching styles and disciplines required of today's college students. Based on this idea McCarthy developed the 4MAT system and added two new views to Kolb's model concerning the way the brain works (right/left mode) (McCarthy, 1990). The 4MAT system is a teaching model based on research on brain function to create a practical teaching method for maximizing human learning and potential. 
Nevertheless, with 4MAT, teachers can facilitate critical dialogue to have students make interpersonal and intrapersonal cognitive development for themselves, by themselves and with each other (Campe, 2006). Learners will, therefore, work in small groups or at times work alone and use their intelligence; visual, interpersonal, musical, bodily-kinesthetic, intrapersonal, linguistic, natural and logical to work at their own pace and create, build, evaluate and extend their learning (McCarthy, 2006). Holistically 4MAT instructional model relies upon the learning loop, which includes four types of students introduced by McCarthy and the right and left hemispheres of the brain, which makes learning a constant process. According to the model, the loops called 4MAT impeller or 4MAT quadrant is divided into eight steps and it is designed as a process that is made up of activities, which are appropriate for the four types of students (learning style) (McCarthy, 2006). In this loop, while the teacher is going around the impeller, the teacher teaches according to learner's differences by utilizing the educational strategies that are appropriate for each student such as experimentation, group discussion, classroom interaction, lecture and other strategies that can stimulate the activities of the two hemispheres (Brent, 2005).

Consequently, teachers should design a framework, which encompasses the 4MAT learning wholly. In addition, considers the individual differences among the students (McCarthy, 2003; Yenice \& Saracaloglu, 2009) 4MAT can be best applied when the skills of the teachers are developed and the education is structured in a way that is suitable for multiple methods to be used so that the students will receive every style of learning (Yenice \& Saracaloglu, 2009). 4MAT requires teachers to present teaching appropriately for each of the four learning styles so that they can develop other learning styles, use their learning styles well, and become successful.

McCarthy concluded that the full cycle of a lesson based on 4MAT would include eight activities, accommodating each of the four types of learning using both left and right brain dominance in each quadrant. Such lessons highlight the style of each learner for some fraction of the whole, and rotation between left and right brain activities gives prime time to the different orientations, which would lead to whole-brain performance. According to the model, if the teacher follows the cycle, the learning style and hemispheric preference of each individual would be addressed at least one-fourth of the instructional times.

In Nigeria, the secondary school Biology curriculum is designed to continue students' investigation into natural phenomena, deepen students' understanding and interest in biological sciences and encourage students' ability to apply scientific knowledge to everyday life (Federal Ministry of Education, 2009). Biology is an important science subject and stands as the bedrock to the learning of other science courses like Medicine, Pharmacy, Nursing, Biochemistry, Genetics and Agriculture that are of great economic importance to the nation. For this reason, Biology has a very high enrolment of students in the external examination (West African Examination Council, 2011).

The objectives of the Biology curriculum according to the National Policy on Education is to prepare students to acquire: adequate laboratory and field skill in Biology, meaningful and relevant knowledge of Biology, the ability to apply scientific knowledge to everyday life in matters of personal and community health and agriculture and reasonable and functional scientific attitude. In pursuance of the above-stated objectives of the biology curriculum, the contents and context of the curriculum place emphasis on field studies, guided discovery, laboratory techniques, and skills along with conceptual attitude (Federal Ministry of Education, 2007). To achieve these objectives of the Biology curriculum, emphasis should be placed on the teaching and learning process in other to allow students to develop their highest potentials (Pratoomtong, 2011). Caine (2002) posited that good teachers should organise classroom activities that emphasize the active role of the learners to construct their knowledge and understanding through interacting with the environment around them. However, these activities should be interesting to learners and appropriate for their developmental level so that they can use their whole brain to participate in them, which will improve their academic achievement.

The objectives of the Biology curriculum according to the National Policy on Education is to prepare students to gain: adequate laboratory and field skills in Biology, meaningful knowledge of Biology, the ability to apply scientific knowledge to everyday life in matters of personal and community health, agriculture, and a reasonable and functional scientific attitude. In pursuance of the abovestated objectives of the biology curriculum, the contents and context of the curriculum emphasize field studies, guided discovery, laboratory techniques, and skills, along with conceptual attitude (Federal Ministry of Education, 2007). To achieve these objectives of the Biology curriculum, they should emphasize the teaching and learning process to allow students to develop their highest potential. This poor achievement of students in biology at the senior school certificate examination leaves one in doubt about the effectiveness of instructional approaches employed by the biology teachers for the teaching and learning of biology. Nwagbo (2001) stated that most biology teachers use conventional lecture methods in the teaching of the subjects. To enhance students' achievement and 
active participation in the learning process in biology, they should place much attention on students' learning styles and their impact on the teaching and learning process.

Gender is a set of characteristics distinguishing male and female, particularly in the cases of men and women. It is a sociological concept that ascribes certain roles to males and females. Although they are internalized very early in life, they vary across social, political, educational, and economic dimensions. Considering the analytic and tasking nature of science, females are socialized early in life to believe that Science, Technology, Engineering, and Mathematics (STEM) are meant for males (Agomouh, 2010). Studies have shown that this is not always the case. Given the nature of interaction that occurs in a 4MAT learning environment, we decided to investigate the effect of 4MAT on biology achievement in Biology along gender lines.

\subsection{Present study}

Consequently, we answer the following research questions (RQs) in the present study: What is the mean achievement score of students with different learning styles taught biology using 4MAT and those taught using the conventional lecture method? What is the difference in the mean achievement score of male and female students taught biology using 4MAT? For these two research questions, we hypothesize that there is no significant difference in the strength of the correlation between pretest and posttest for students in treatment learning style and control learning style in Biology. There is no significant difference in the mean achievement scores of students with different learning styles taught Biology using 4MAT. There is no significant difference in the mean achievement scores of male and female students taught Biology using 4MAT.

\section{Methods}

\subsection{Design}

We conducted the study as a pre-post intervention study with a control group. The study was quasi-experimental and used a nonequivalent groups design. We selected the groups based on a convenience sample without randomisation. Quasi-experiments are useful when random allocation is difficult, for example, in educational field interventions (Bryman, 2008, p. 40-41; Price et al., 2015). The intervention consisted of 6 lessons over six weeks. In this quasi-experimental design, three teachers each taught two different preexisting classes. For each teacher, we randomly allocated one of their classrooms to the intervention condition and the other to the control condition to balance the impact of teacher effects in our design.

\subsection{Participants}

An a priori power analysis was conducted using G*Power3 (Faul, Erdfelder, Lang, \& Buchner, 2007) to test the difference between two learning styles independent group means using a two-tailed test, a large effect size $(d=.40)$, and an alpha of .05. We performed a priori power analysis to determine the sample size we need to reach a desired level of power. The result showed that a total sample of 138 participants with two unequal sized groups of $n=71$ and 67 was required to achieve a power of .90 .

Place Figures 17 to 18 here

We enrolled one hundred and thirty-eight Senior Secondary School Two students (SSS 11) (11th Grade) in the experiment. The age range was narrow: from sixteen (64 students) to seventeen (74 students) years old. There were 56 (40.58\%) males and 82 (59.42\%) females. We divided the participants into two groups of $71(51.45 \%)$ and 67 (48.55\%) participants each without any criteria of choice. These represented the treatment and control groups respectively. We considered logical ethical issues before starting the intervention. Ethical approval was obtained from the Faculty of Education, University of Nigeria Ethics Review Board. We obtained permission from the headteachers of the schools we used for the study. We also sought and obtained the consent of the parents of the students used in different aspects of the study. We held a conference with research assistants who were class teachers of the students that we used for the study. In the conference, we briefed the teachers on how to carry on with the intervention.

We experimented with two secondary schools in Abakaliki Local Government Area, Ebonyi State, Nigeria. We used the convenience sample technique to select the two secondary schools from 18 co-educational public secondary schools in Abakaliki. The 138 students were located in four intact classes (two in each of the sampled schools) based on their different learning styles. 


$\begin{array}{lcr}\begin{array}{l}\text { Description of } \\ \text { Learning Style }\end{array} & \text { Frequency (n) } & \text { Percentage (\%) } \\ \text { Intervention Group } & & \\ \text { Diverging } & 23 & 16.67 \\ \text { Assimilating } & 10 & 7.25 \\ \text { Converging } & 21 & 15.22 \\ \text { Accommodating } & 17 & 12.32 \\ \text { Total } & 71 & 51.45 \\ \text { Control Group } & & \\ \text { Diverging } & 18 & 13.04 \\ \text { Assimilating } & 26 & 18.84 \\ \text { Converging } & 11 & 7.97 \\ \text { Accommodating } & 12 & 8.70 \\ \text { Total } & 67 & 48.55 \\ \text { Grand Total } & 138 & 100 \\ \end{array}$

\subsection{Materials}

\subsubsection{Biology Achievement Test (BAT) and Learning Style Inventory (LSI)}

The instrument used for data collection in the study was Biology Achievement Test (BAT). The BAT was validated by three experts from the Department of the Science Education University of Nigeria, Nsukka and trial-tested on 22 Biology students within the vicinity of the study area. This was to ensure that it is valid and reliable for the intended population. We designed the Biology Achievement Test (BAT) to assess the students' achievement in Biology. This instrument was designed to cover the scope of the content of the study which is Respiratory System Concepts as stated in the senior secondary school biology curriculum. The experts scrutinized the instruments in terms of relevance, general format, suitability, structure, and adequate timing. A clear concept of the Respiratory System was covered. We modified the instructions along the line suggested to make them clearer to the students. We established the Content validity through the agreement of experts on the table of the specification that guided the development of BAT. The 60-item comprises Matching and Filling the gap multiple-choice questions. The time allowed for the test was 50 minutes. A marking scheme was prepared and used to score the test. The reliability estimate was established for BAT using Kudder-Richardson formula 20 and it yielded a reliability index of .91 this was considered adequate for the study.

\subsubsection{Learning Style Inventory (LSI) adapted from Kolb and Kolb, (2005)}

We used the Learning Style Inventory (Kolb \& Kolb, 2005) to classify the participants according to their different learning styles namely Diverging, Assimilating, Converging, and Accommodating. The learning style inventory was administered to the students to fill and the students were given numbers, which they were asked to write at the top left side of the learning style inventory for easy identification of the students when returning the inventory to them. The students filled the inventory as they were instructed to and submitted it to their class teachers who handed them back to the researchers for scoring. After scoring and categorizing the students based on their learning styles, copies of the inventories were returned to the respective students using the numbers assigned to them and they used the information about their learning style to fill the column on learning style in the tests. A pre-achievement test was administered to the students before the treatment to provide the researchers with baseline data about the subjects.

\subsection{Procedure}

Adherence to the intervention protocol was ensured. At the onset of the experiment, the research assistants administered LSI to the SSII Biology students to determine their different learning styles and to categorize them accordingly. The teachers gave the subjects for both the treatment and control groups the BAT as the prior knowledge test during regular class time. The students received the instruction as normal classroom instruction from their teachers. Teachers were told not to change their usual teaching interaction with their students and received instructions and training on how to apply the learning materials for each lesson.

Thereafter the teachers began the experiment adhering strictly to the lesson procedure developed for the groups. Each lesson of 40 minutes started with retrieval practice activities about the content and a discussion of the quiz questions from the workbooks. This was usually followed by a complementary micro-teaching of approximately 10 minutes to discuss parts that were not yet fully understood as well as more in-depth aspects of the learning material. Six lessons were prepared, each on teaching Respiratory System concepts using 4MAT and the conventional method which is lecture dominated. The teachers taught the students properly 
during the experiment. The experimental group was taught using 4MAT and the control group was taught using the conventional method. The teachers experimented during the normal lesson periods as provided in the timetable. The remaining part of the lesson was dedicated to engaging learning activities to apply the learning material (e.g. drawing of diagrams).

By the end of the experiment, which lasted for six weeks, the class teachers shuffled the items on the pretest and administered them to the students as a posttest. We analyzed the data collected and used it to answer the research questions and test the hypotheses.

\subsection{Analysis}

Statistical analysis was done with SPSS Version 25 (IBM Corporation, Armonk, NY, USA). All variables were centred and standardized for analysis. Alpha (a) levels for hypothesis testing was set at the.05 levels (two-tailed). We performed a hierarchical Analysis of Covariance (ANCOVA) on pretest and posttest obtained from the SSII students to evaluate the intervention effect and Pearson correlation for comparing correlation coefficients for the two groups: Intervention learning style and Control learning style with pretest and posttest. The independent variable was the group status of control vs. intervention. The covariate was pretest scores obtained from the students before the intervention.

We conducted preliminary checks to ensure that there was no violation of the assumptions of normality, linearity, homogeneity of variances, homogeneity of regression slopes, reliable measurement of the covariate, two groups were independent, distribution of scores for the two groups is assumed to be normal and we have more than 20 cases in each of the groups. We show these schematically in figures 1 to 14 in Appendix A.

\section{Results}

We presented the results in Tables 1, 2, and 3. We also, show the results graphically in Figures 1 and 2.

Research Question 1: What is the mean achievement scores of students with different learning styles taught biology using 4MAT and those taught using the conventional lecture method?

\section{Table 1: Mean $(\overline{\mathrm{X}}$ and Standard Deviation (SD) on mean achievement score of students with different learning styles taught biology using 4MAT}

1 .

\begin{tabular}{|c|c|c|c|c|c|c|}
\hline \multirow{2}{*}{$\begin{array}{c}\text { METHODS } \\
\text { 4MAT }\end{array}$} & \multicolumn{3}{|c|}{ PRE-TEST } & \multicolumn{2}{|c|}{ POST-TEST } & \multirow{2}{*}{$\begin{array}{c}\underset{\bar{X}}{\text { ADJUSTED MEAN }} \\
\end{array}$} \\
\hline & $\mathrm{N}$ & $\overline{\mathbf{X}}_{1}$ & $\mathrm{SD}_{1}$ & $\overline{\mathbf{X}}_{2}$ & $\mathrm{SD}_{2}$ & \\
\hline Diverging & 23 & 18.96 & 4.23 & 30.57 & 4.67 & 26.91 \\
\hline Assimilating & 10 & 16.80 & 3.58 & 29.60 & 4.72 & 28.09 \\
\hline Converging & 21 & 13.67 & 2.42 & 30.67 & 2.22 & 32.16 \\
\hline Accommodating & 17 & 14.41 & 3.91 & 26.18 & 4.72 & 27.05 \\
\hline LECTURE & & & & & & \\
\hline Diverging & 18 & 13.39 & 4.88 & 20.72 & 6.68 & 22.51 \\
\hline Assimilating & 26 & 14.81 & 3.84 & 24.38 & 6.07 & 24.78 \\
\hline Converging & 11 & 16.55 & 3.96 & 24.18 & 7.05 & 23.01 \\
\hline Accommodating & 12 & 13.17 & 4.39 & 20.92 & 7.39 & 22.84 \\
\hline
\end{tabular}

Data in Table 1 showed that in the treatment group (4MAT), students with converging learning style had pretest $(M=13.67, S D=2.42)$ and posttest $(M=30.67, S D=2.22)$ with the highest adjusted mean score of 32.16 , followed by assimilating learning style pretest ( $M$ $=16.80, S D=3.58)$ and posttest $(M=29.60, S D=4.72)$ with adjusted mean of 28.09. The students with accommodating learning style had pretest $(M=14.41, S D=3.91)$ and posttest $(M=26.18, S D=4.72)$ and adjusted mean of 27.05 . Similarly, diverging learning style students had pretest $(M=18.96, S D=4.23)$ and posttest $(M=30.57, S D=4.67)$ with the adjusted mean score of 26.91. In the (lecture) group, students with assimilating learning style had pretest $(M=14.81, S D=3.84)$ and posttest $(M=24.38, S D=6.07)$ with the highest adjusted mean score of 24.78 , followed by converging learning style pretest $(M=16.55, S D=3.96)$ and posttest $(M=$ $24.18, S D=7.05)$ with the adjusted mean score of 23.01. The students with accommodating learning style had pretest $(M=13.17, S D$ $=4.39)$ and posttest $(M=20.92, S D=7.39)$ with the adjusted mean of 2.84. Likewise, students with the diverging learning style had pretest $(M=13.39, S D=4.88)$ and posttest $(M=20.72, S D=6.68)$ with adjusted mean score of 22.51. These results indicated that students with different learning styles in the treatment group had almost the same high level of achievement while in the control group; only the students with assimilating learning styles had a considerable high level of achievement. The result showed that 
students taught biology using 4MAT had a higher mean achievement score than their counterparts taught using the conventional lecture method.

$\mathrm{HO}_{7}$ : There is no significant difference in the strength of the correlation between pretest and posttest for students in 4MAT learning style and conventional lecture method learning style in Biology.

Table 2

A correlation matrix for learning styles and biology achievement at both pretest and posttest

\begin{tabular}{|c|c|c|c|c|}
\hline Method & & & Pretest & Posttest \\
\hline \multirow[t]{6}{*}{ 4MAT } & Pretest & Pearson Correlation & 1 & $.407 \star \star$ \\
\hline & & Sig. (2-tailed & & .000 \\
\hline & & $\mathrm{N}$ & 71 & 71 \\
\hline & Posttest & Pearson Correlation & .407 & 1 \\
\hline & & Sig. (2-tailed & .000 & \\
\hline & & $\mathrm{N}$ & 71 & 71 \\
\hline \multirow[t]{6}{*}{ Lecture } & Pretest & Pearson Correlation & 1 & $.847 \star \star$ \\
\hline & & Sig. (2-tailed & & .000 \\
\hline & & $\mathrm{N}$ & 67 & 67 \\
\hline & Posttest & Pearson Correlation & .847 & 1 \\
\hline & & Sig. (2-tailed & .000 & \\
\hline & & $\mathrm{N}$ & 67 & 67 \\
\hline
\end{tabular}

In Table 2, we converted the $r$ values into $z$ scores using Fisher's $r$ to $z$ transformation (Glen, 2021). This was done so that the $z$ scores can be compared and analyzed for statistical significance by determining the observed $z$ test statistic. Then we used the equation to calculate the observed value of $z$ ( $Z_{\text {obs }}$ value). We assessed the value obtained using a set decision rule to determine the likelihood that the difference in the correlation noted between the two groups could have been due to chance. 
4MAT Learning Style: $\mathrm{r}_{1}=.407$

$$
\begin{array}{ll}
\mathrm{N}_{1}=71 & \mathrm{~N}_{2}=67
\end{array}
$$

The corresponding values of each group are:

4MAT Learning Style: $Z_{1}=.436$

Lecture Learning Style: $Z_{2}=1.256$

Using the equation

$$
\begin{aligned}
Z_{\mathrm{obs}} & =\frac{\mathrm{Z}_{1}-\mathrm{Z}_{2}}{\frac{1}{\frac{1}{\mathrm{~N}_{1}-3}+\frac{1}{\mathrm{~N}_{2}-3}}} \\
\mathrm{Z}_{\mathrm{obs}} & =\frac{.436-1.256}{\frac{1}{71-3}+\frac{1}{67-3}} \\
\mathrm{Z}_{\mathrm{obs}} & =\frac{-0.82}{\frac{1}{68}+\frac{1}{64}} \\
Z_{\mathrm{obs}} & =\frac{-.082}{\sqrt{0.0147058823529}+0.015625} \\
Z_{\mathrm{obs}} & =\frac{-.082}{\sqrt{0.0303308823529}}=-.471 \\
Z_{\mathrm{obs}} & =\frac{-.082}{0.1741576365}
\end{aligned}
$$

In the calculation above for the two groups of students namely 4MAT learning style and lecture method learning style, we obtained a $z_{\text {obs }}$ value of -.471 . This is outside the specific bounds of if $z_{\text {obs }}$ is less than or equal to -1.96 or $z_{\text {obs }}$ is greater than or equal to 1.96 . However, we concluded that there is a statistically significant difference in the strength of the correlation between pretest and posttest for 4MAT learning style and lecture method learning style. We, therefore reject the null hypothesis. Pretest explains significantly more of the variance in posttest for lecture method learning style than for 4MAT learning style.

Research Question 2: What is the difference in the mean achievement score of male and female students taught Biology using 4MAT?

Table 3: Mean $\bar{\chi}$ ) and Standard Deviation (SD) on the Influence of Gender on the Mean Achievement Score of Students taught Biology using 4MAT

\begin{tabular}{lcccccc}
\hline \multirow{2}{*}{ GENDER } & \multirow{N}{*}{} & \multicolumn{2}{c}{ PRE-TEST } & POST-TEST & \multirow{2}{*}{ ADJUSTED MEAN } \\
& & $\overline{\mathrm{X}}_{1}$ & $\mathrm{SD}_{1}$ & $\overline{\mathrm{X}}_{2}$ & $\mathrm{SD}_{2}$ & \\
\hline Male & 56 & 15.13 & 3.97 & 26.59 & 6.20 & 26.63 \\
Female & 82 & 15.30 & 4.56 & 25.89 & 6.82 & 25.86 \\
\hline
\end{tabular}

Data in Table 3 showed that male students taught Biology using 4MAT had pretest $(M=15.13, S D=3.97)$ and posttest $(M=26.59, S D$ $=6.20)$ with the adjusted mean score of 26.63 while their female counterparts had pretest $(M=15.30, S D=4.56)$ and posttest $(M=$ $25.89, \mathrm{SD}=6.82$ ) with an adjusted mean score of 25.86. The result showed that male students who were taught Biology using $4 \mathrm{MAT}$ had a higher mean achievement score than their female counterparts did.

$\mathrm{HO}_{2}$ : There is no significant difference in the mean achievement scores of students with different learning styles, taught Biology using 4MAT and those taught with the conventional method.

Table 4: Analysis of Covariance of Students' Achievement Scores by Learning Styles and Gender 


\begin{tabular}{clllllll}
\hline & & \multicolumn{7}{c}{ Hierarchical Method } \\
\cline { 3 - 8 } & & Sum of & \multicolumn{1}{c}{ Mean } & & & \\
Posttest & & Squares & df & Square & F & Sig & $\eta^{2}$ \\
Main Effects & Pretest & 2484.747 & 1 & 2484.747 & 162.471 & .000 & .448 \\
& (Combined) & 1373.626 & 8 & 171.703 & 11.227 & .000 & \\
& Method & 1354.668 & 7 & 193.624 & 12.654 & .000 & .394 \\
2-WayInteractions & Gender & 18.958 & 1 & 18.958 & 1.240 & .268 & .004 \\
Model & Learning Styles*Gender & 184.940 & 7 & 26.420 & 1.728 & .109 & .091 \\
Residual & & 4043.313 & 16 & 252.707 & 16.524 & .000 & \\
Total & & 1850.513 & 121 & 15.293 & & & \\
\hline
\end{tabular}

Data in Table 4 showed a statistically significant main effect of the instructional method on the mean achievement score of students in Biology $F(7,121)=12.654, p=.000$, partial $\eta^{2}=.39$. The eta-squared statistic indicated a large effect. We rejected the null hypothesis, showing that there was a significant difference in the mean achievement scores of students with different learning styles taught biology using 4MAT, and those taught using the conventional lecture method. There was a strong relationship between the pretest and posttest scores on the achievement test, as indicated by a partial eta squared value of .45

$\mathrm{HO}_{2}$ : Gender does not significantly influence the mean achievement scores of students in biology when taught using 4MAT

Data in Table 3 showed a non-statistical significant main influence of gender on students achievement in biology $F(1,121)=1.240, p=$ .268 , partial $\eta^{2}=.004$. The eta-squared statistic indicated a small effect. We did not reject the null hypothesis, showing that there was no significant difference in the mean achievement scores of male and female students taught biology using 4MAT.

\section{Discussion}

\subsection{Four Mode Application Techniques (4MAT) on the achievement of a student with different learning styles in Biology}

Four Mode Application Technique (4MAT), was superior to the conventional lecture method in facilitating the achievement of the learners with different learning styles. The test of hypothesis also showed that there was a significant difference in the mean achievement scores of students with different learning styles taught biology using 4MAT and those taught using the conventional lecture method. These differences in achievement scores of students with different learning styles might have been because of the type of instructions presented to them. In the 4MAT lesson, all learners had equal chances of learning and constructing their knowledge. There was also a more interactive exchange of information than just giving formation. 4MAT creates opportunities for a deeper sense of responsibility for the student during the learning process. The activities allowed the students to learn concepts more than contents and provided opportunities for students to express free opinions with the teachers as a facilitator. Therefore, the students who learned through 4MAT continuously encourage the whole- brain functioning in constructing knowledge.

When the students generated information, they seemed to understand their knowledge better than the one presented by the teachers. In addition, in the 4MAT lesson, there were activities for each student's learning style. The four types of learners identified in the model need to learn like each other at the same time in other to make learning successful that is the type one learner has to learn how to be type two, three, and four learner etc., if he should learn anything well. The contents and activities were suitable for the potential and diversity of students. This could be the reason why the students who were taught biology using 4MAT performed better than their counterparts do teach biology using the conventional lecture method.

The result of the study showed that among those exposed to biology lessons based on the conventional lecture method; the students with assimilating learning styles had considerable high achievement scores. This is because students with assimilating learning styles learn best when exposed to instruction based on the lecture method. The finding of this study is in line with the observations of Pratoomtong (2011) who found that students who learned through science activities based on the 4MAT System had higher achievement than students who learned through the traditional method of teaching. The study also agreed with the observations of Taylor and Francis (2009), Phatchariya-Phetdong (2005), Piyalux-Potiwan (2004), Nitita (2002) and Doughathai (2001), who found out that students taught with 4MAT achieved significantly better than students in the textbook group. 


\subsection{Influence of gender on mean achievement scores of students taught biology using 4MAT}

The findings of this study revealed that male students had slightly higher mean achievement scores than their female counterparts. The difference in the mean achievement scores for male and female students was not statistically significant. This finding could be because of the nature of the instructional method used in teaching the students, which is 4MAT. All the students were given equal opportunities and were actively involved in the instructional process. This instructional model allowed both the male and female students to find out facts by themselves on the same level ground. This method also helped to engage actively the students with different learning styles and hemispheric preferences to learn at the same pace. The findings from this study agreed with the findings of Ukozor (2011) and Madu (2004) who found out those male students performed better than their female counterparts in physics. This finding also agreed with that of Nwosu (2001) and Baser (2006) who found out that gender is not a significant factor in the mean achievement score of students in biology.

\subsection{Educational Implications of the Findings of the Study}

The findings of this study imply the Education, Science and Education community in particular, which includes the biology students, biology teachers, authors, and publishers of biology books.

The implications of this study border on the use of the more virile instructional method for teaching biology. The findings of this study have shown that students have difficulties in biology and these difficulties are resistant to change. These results imply that the current instructional methods used in teaching biology cannot effectively enhance the achievement of students with different learning styles. Therefore, the instructional method that can take care of the differences in students' hemispheric preferences and learning styles would be more appropriate in teaching biology. 4MAT was able to engage the function of the two hemispheres of the brain and address the needs of students with different learning styles, thereby enhancing the achievement, retention and multiple intelligences of a student with a different learning style.

The findings also have implications for instructing students who differ in learning styles and hemispheric preferences. The use of 4MAT would be more effective irrespective of the differences in learning styles and hemispheric preference.

\subsection{Recommendations}

The researchers made the following recommendation:

Teaching and learning through 4MAT was observed that most students were very interested, enthusiastic, had fun, and were happy because they did experiments and activities by themselves as well as working in groups with friends. Therefore, teachers should apply these activities to other content areas in biology at different levels.

\subsection{Limitations of the Study}

Since different teachers were used for the different groups in this study, it could be assumed that they might not have been of equal attributes in terms of cognition, personality, and effective functioning. This might have introduced an error in the study.

\subsection{Suggestions for Further Studies}

Further studies should be aimed to investigate multiple intelligences and creative thinking of students with different learning styles taught on any science subject using 4MAT.

\section{Conclusion}

From the results obtained in the study, it was found that 4MAT was superior to the conventional lecture method in enhancing the achievement of students with different learning styles in biology and gender significantly influenced students' mean retention scores in biology when taught using 4MAT,

\section{Declarations}

\section{Acknowledgements}


We would like to thank our study participants for their time as well as Jude Ugwu, Ladi, Elizabeth Iheabunike, and Ozor Sergius for their assistance with data collection.

\section{Author Contributions}

All the authors contributed to the study formation and design. Chris Ibenegbu performed material preparation, data collection, and analysis. Chris Ibenegbu wrote the first draft of the manuscript and Queendaline commented on the former versions of the manuscript. All the authors read and approved the final manuscript.

\section{Consent}

We obtained consent from all individual participants included in the study.

\section{Data Availability}

The data set we generated during and/or analyzed during the current study are not publicly available due to confidentiality issues but are available from the corresponding author on request.

\section{Competing interests}

The authors declare that they have no competing interests.

\section{Ethical approval}

We obtained both oral and written consent from the participants. The parents or guardians of the students below the age of 18 years provided both oral and written consent on their behalf. Participation was voluntary. The Local Institutional Review Board (Postgraduate Studies Review Board), University of Nigeria, Nsukka approved the study procedure.

Before participants' verbal consent, we informed them about the purpose of the study and we made them understand that participation was voluntary and refusal to participate in the study attracts no penalty. We assured the study respondents of confidentiality and we removed personal identifiers in the summary data to ensure confidentiality.

\section{References}

1. Adejeji, S.O. (2013). Increasing girls access to technical and vocational education in Nigeria. Ibadan: Macmillan Publisher Nigeria.

2. Agama, T. L. (2009). The effect of the game of method teaching on student's Academic Achievement in Chemistry. Journal of Science Teachers Association of Nigeria. 44, (1\&2), 212-217

3. Agomouh, P. C. (2010). Effect of prior knowledge, exploration, discussion, dissatisfaction with prior knowledge and application (PEDDA) and the learning cycle (TLC) constructivist instructional models on students' conceptual change and retention. [Unpublished PhD Thesis]. University of Nigeria, Nsukka.

4. Baser, M. (2006). Fostering conceptual change by cognitive conflict is based on students' understanding. Eurasian Journal of Mathematics, Science and Technology Education. 4 (16), 45-55.

5. Bielefeldt, S. D. (2006). An analysis of right- and left-brain thinkers and certain styles of learning. [Master of Science Degree], Graduate School University of Wisconsin -Stout

6. Blair, P \& Juda, S. (1990). The effect of the 4mat system on achievement and attitudes in science. http://www.eric.ed.gov/ERICDocs/data/ericdocs2sql/content_storage_01/0000019b/80/1c/84/f1.pdf.

7. Bland, L. (2003). Oversold and underused: computers in the classroom. Cambridge, MA: Harvard University Press.

8. Brown, B. L. (2003). Teaching style vs. learning style. http://www.4mat.eu/media/17164/rg1.historical\%20\&\%20theoretical\%20perspective.pdf

9. Bryman, A. (2008). Social research methods (3rd. ed.). Oxford: Oxford University Press.

10. Byrne, D. (2002). A study of individual learning styles and educational multimedia preferences: An Experiment using self-directed online learning resources. http://www.compapp.dcu.ie/ mfarren/denice.PDF

11. Campbell, L. (2009). How Teachers Interpret MI Theory. Educational Leadership. 55(1), 14-19

Page $12 / 23$ 
12. Campe, K. (2006). My Philosophy of Teaching. http://www2.gvsu.edu/morseli/philosophy.pdf

13. Chatuporn, L. (2002). A proposed model of organizing integrated non-formal education activities for the prevention of aids among students of general non-formal education at lower secondary education, distance learning type in Bangkok metropolis. [Unpublished Master's Project]. Bangkok: Chulalongkorn University.

14. Dounghathai, S. (2001). The effects of using the 4MAT lesson plan on learning achievement responsibility and learning attitude in the education population unit and the occupational unit Prathomsuksa [Unpublished Master's Project]. Bangkok: Srinakharinwirot University.

15. Dunn, R. \& Griggs, S. A. (2000). A meta-analytic validation of the Dunn and Dunn model of learning style preferences. The Journal of Educational Research. 88(6), 353-

362. http://katherinecampe.com/resources/Teaching+Philosophy.doc. http://www.americanjournalofpsychologicalresearch.com

16. Faul, F., Erdfelder, E., Lang, A. G., \& Buchner, A. (2007). G*Power 3: A flexible statistical power analysis program for the social, behavioural, and biomedical sciences. Behaviour Research Methods, 39, 175-191. 5.

17. Glen, S. (2020). Elementary statistics for the rest of us. Fisher z-transformation from statistics. <bi>Statistics How to.com</bi> https://www.statisticshowto.com/fisher-z/

18. Kolb, A.Y. \& Kolb, D. A. (2005). The Kolb Learning Style Inventory - Version 3.1: 2005 technical specifications. Haygroup: Experience Based Learning Systems Inc.

19. Madu, B. C. (2004). Effect of a constructivist- Based instructional model on students' conceptual change and retention in physics. [Unpublished PhD Thesis]. University of Nigeria, Nsukka

20. McCarthy, B. (1987). The 4MAT system: Teaching to learning styles with right/left mode techniques. Barrington, IL: Excel.

21. McCarthy, B. (1990). Using the 4MAT system to bring learning styles to schools. Educational Leadership. 48(2), 31-37.

22. McCarthy, B. (2006). Teaching around the 4MAT cycle: Designing instruction for diverse learners with diverse learning styles. Thousand Oaks, CA: Corwin Press.

23. Merrill, P. (1990). Perceptual learning style. Educational Leadership. 60(1) 70-73.

24. More, B. D. (2003). The Relationship of 5th Grade Students Self Concept and Attitude towards Biological Concepts and Applications. [Unpublished PhD Thesis]. University of Nigeria, Nsukka.

25. Nitita, K. (2002). A comparison of the effects of McCarthy's learning (4MAT) and group dynamics on the creativity of Pratham Suksa II students of Sawasdeewittaya school in Khet Vadhana, Bangkok. [Unpublished Master's Thesis]. Bangkok: Srinakharinwirot University.

26. Nwagbo, C. R. (2001). The relative efficacy of guided inquiry and expository methods for achievement in biology students of different levels of scientific literacy. Journal of Science Teacher Association of Nigeria 36 (1\&2), 43-51.

27. Oflaz, M. (2011). The effect of right and left brain dominance in language learning. Procedia Social and Behavioral Sciences, 15 (2011), 1507-1513.

28. Phatchariya, P. (2005). The outcome of learning and teaching of science for prathomsuksa v to sound by the 4MAT model. [Unpublished MEd Project]. (Science Education). Khon Kaen: Khon Kaen University.

29. Piyalux, P. (2004). The development of instructional activities for grade-10 covalent molecular subjects based on the 4MAT cycle of learning. [Unpublished Master's Project] (Science Education). Khon Kaen: Khon Kaen University.

30. Price, P. C., Jhangiani, R. S. \& Chiang, I-C. A. (2015). Research methods in psychology (2nd. ed.). OpenEd. https://opentextbc.ca/researchmethods/

31. Reynolds, W. B. (2007). Different strokes for different folks?: A Critique of learning styles. http://www.vim3.April2008libaried.edu.pdf

32. Rochford, R. R. (2012). Assessing experiential learning styles: a methodological reconstruction and validation of the Kolb learning style inventory. Learning and Individual Differences. DOI:10.1016/j.lindif.2012.10.009

33. Roy. C. B. (2007). Colloquium: Considering learning style in computer-assisted learning. British Journal of Educational Technology 28(1) 66-8.

34. Soyoof, A., Jokar, M., Ali, M., Razavizadegan, C., \& Morovatd, E. (2014). The Effects of Learners' Brain Hemisphericity on their Degree of Vocabulary Retention: A Case Study of Iranian High School Students. Procedia - Social and Behavioral Sciences 98. 
35. Stitt-Gohdes, W. (2001). Business education students and preferred learning styles and their teachers' preferred instructional styles: Do they match? Delta Phi Epsilon Journal, 43, 137-1 51.

36. Taylor.O. O. \& Francis, J. I, (1997). Balancing Innovation and Tradition to Create Learning Opportunities for All Learners. Paper Presented at the Sixth Annual International Conference for Community \& Technical College Chairs, Deans, and Other Organizational Leaders. Nevada.

37. Ubah, J. N. (2012). Learning styles among medical students, a case study of Ladoke Akintola University of Technology Medical School, Osogbo. Journal of Education and Practice 3 (5) 211-116

38. Ukozor, F. I. (2011). Effect of constructivist teaching strategy on senior secondary school students' achievement and self-efficacy in physics. African Journal of Science and Mathematics Education 1 (1), 141-160

39. Wilkerson, R. M. \& White, K. P. (1988). Effects of the 4MAT System of Instruction on Students' Achievement, Retention, and Attitudes. The Elementary School Journal. 88(4) 357-368.

40. Yenice, N., \& Saracaloglu, A. S. (2009). The relationship between learning styles and science achievement of pre-service elementary school teachers. http://www.com/fulltext/oks/info/Jack-R-Fraenkel/Hdoi=pjSsc

\section{Figures}

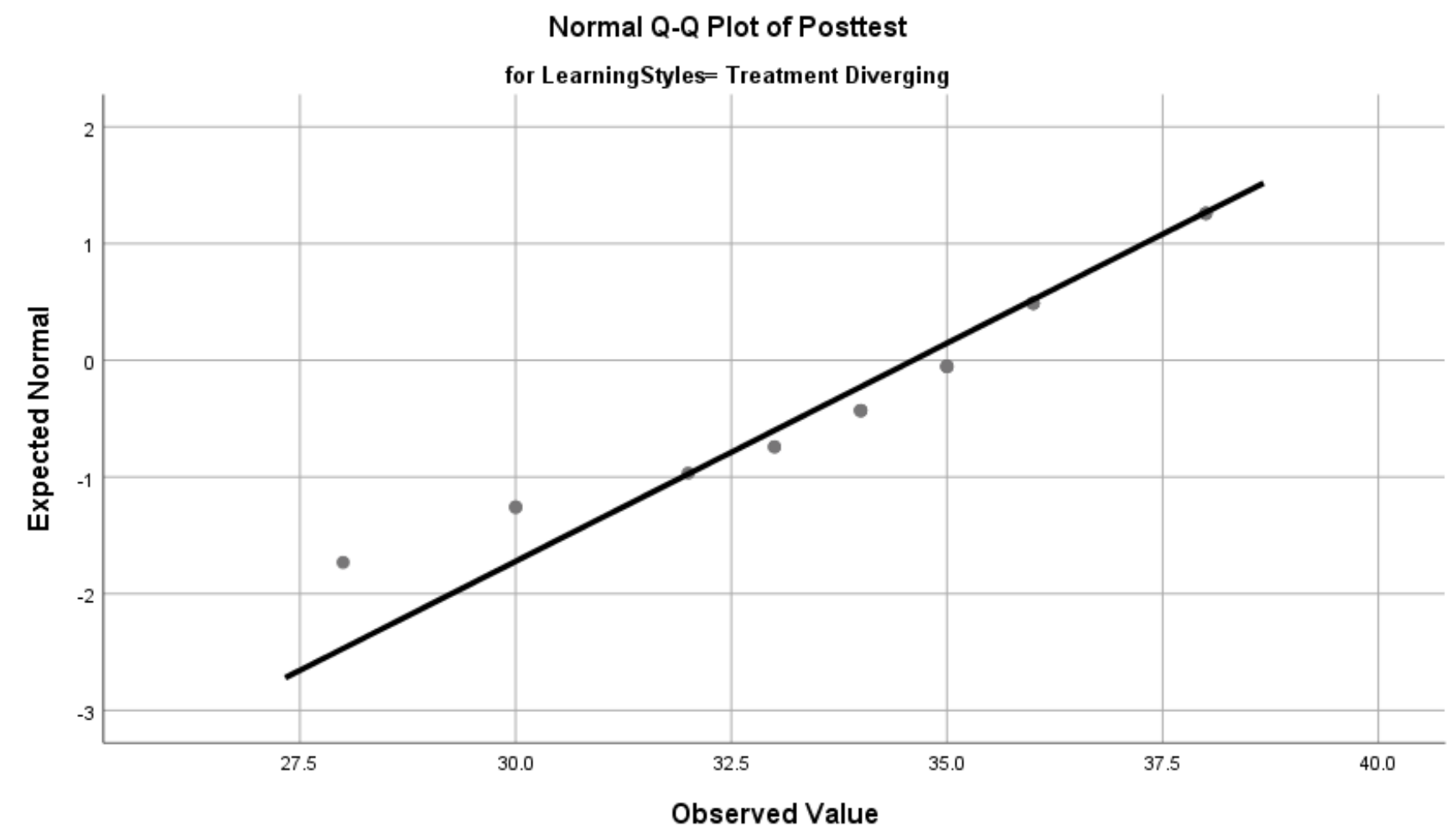

Figure 1

Q-Q Scatterplot Testing Normality for $4 M A T$ 


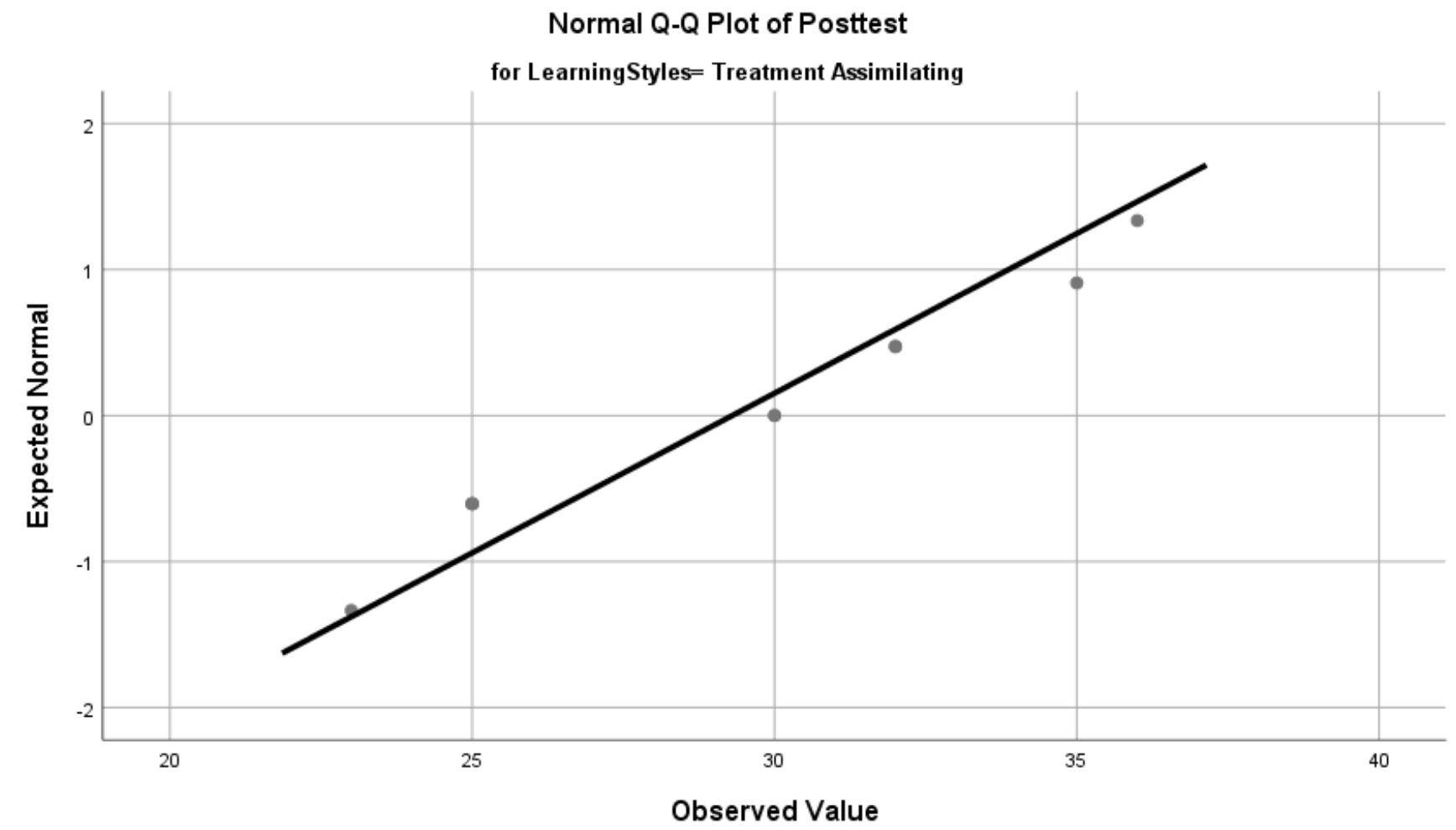

Figure 2

Q-Q Scatterplot Testing Normality for 4MAT

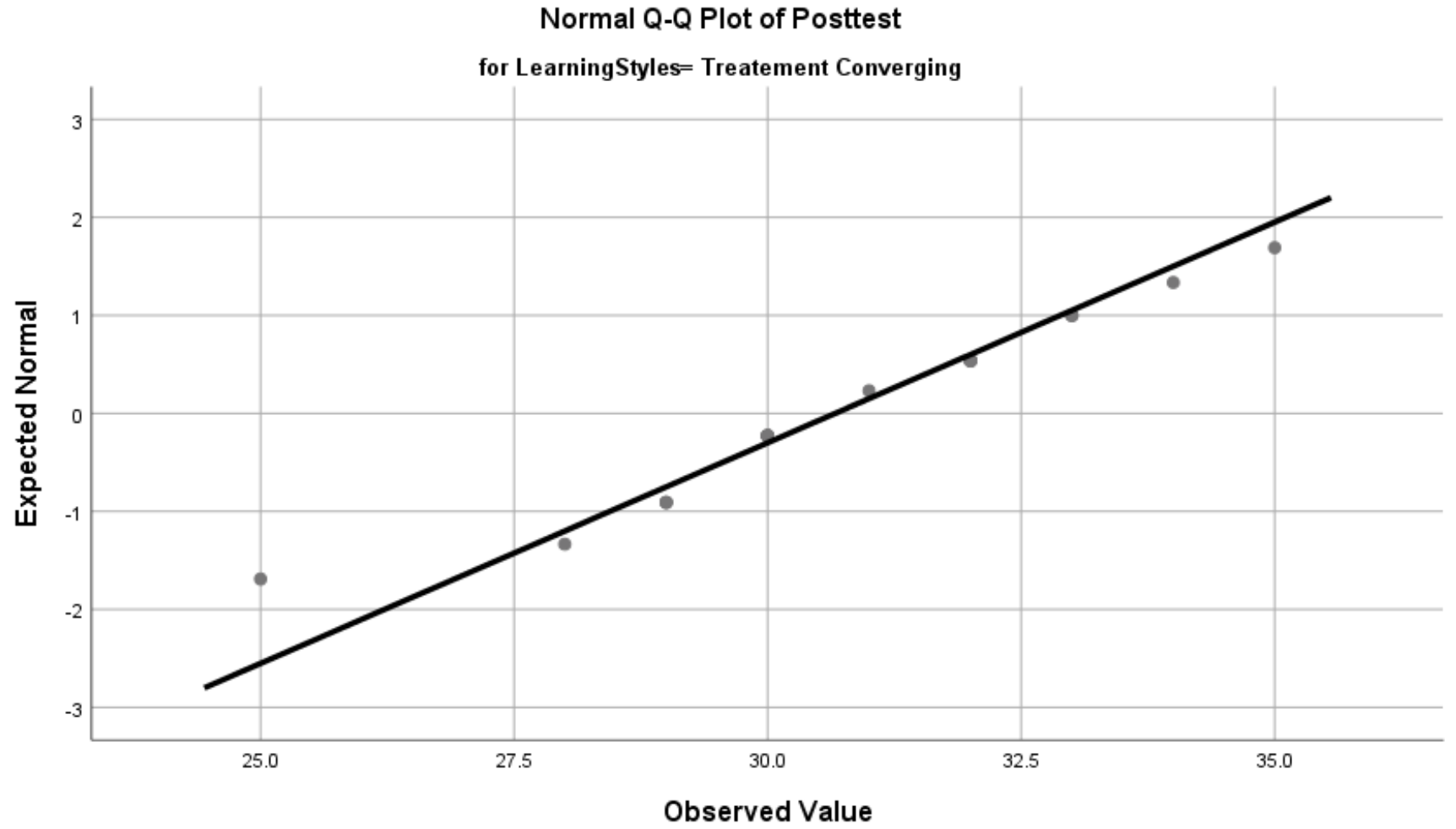

Figure 3

Q-Q Scatterplot Testing Normality for 4MAT

Page $15 / 23$ 


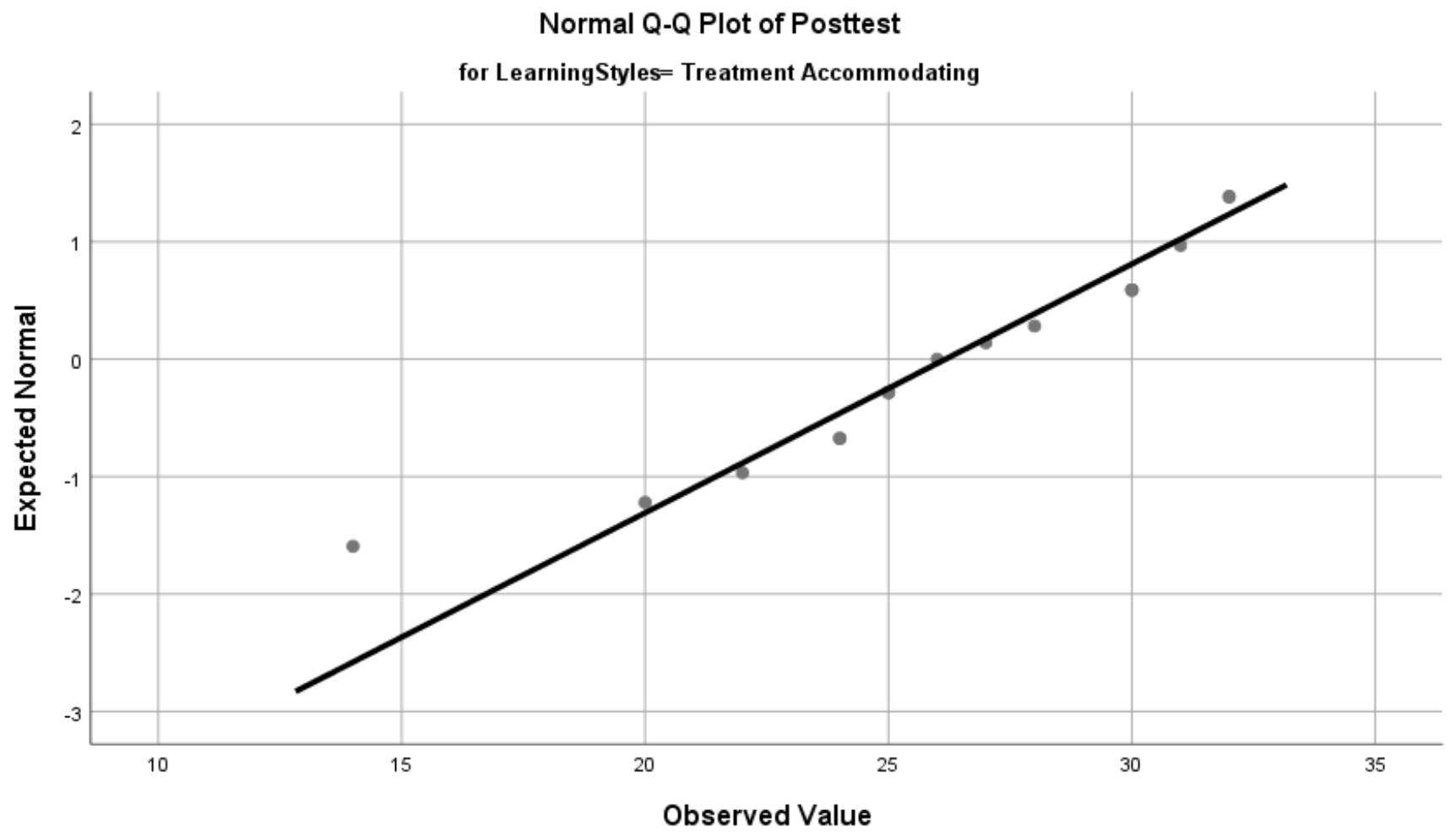

Figure 4

Q-Q Scatterplot Testing Normality for 4MAT

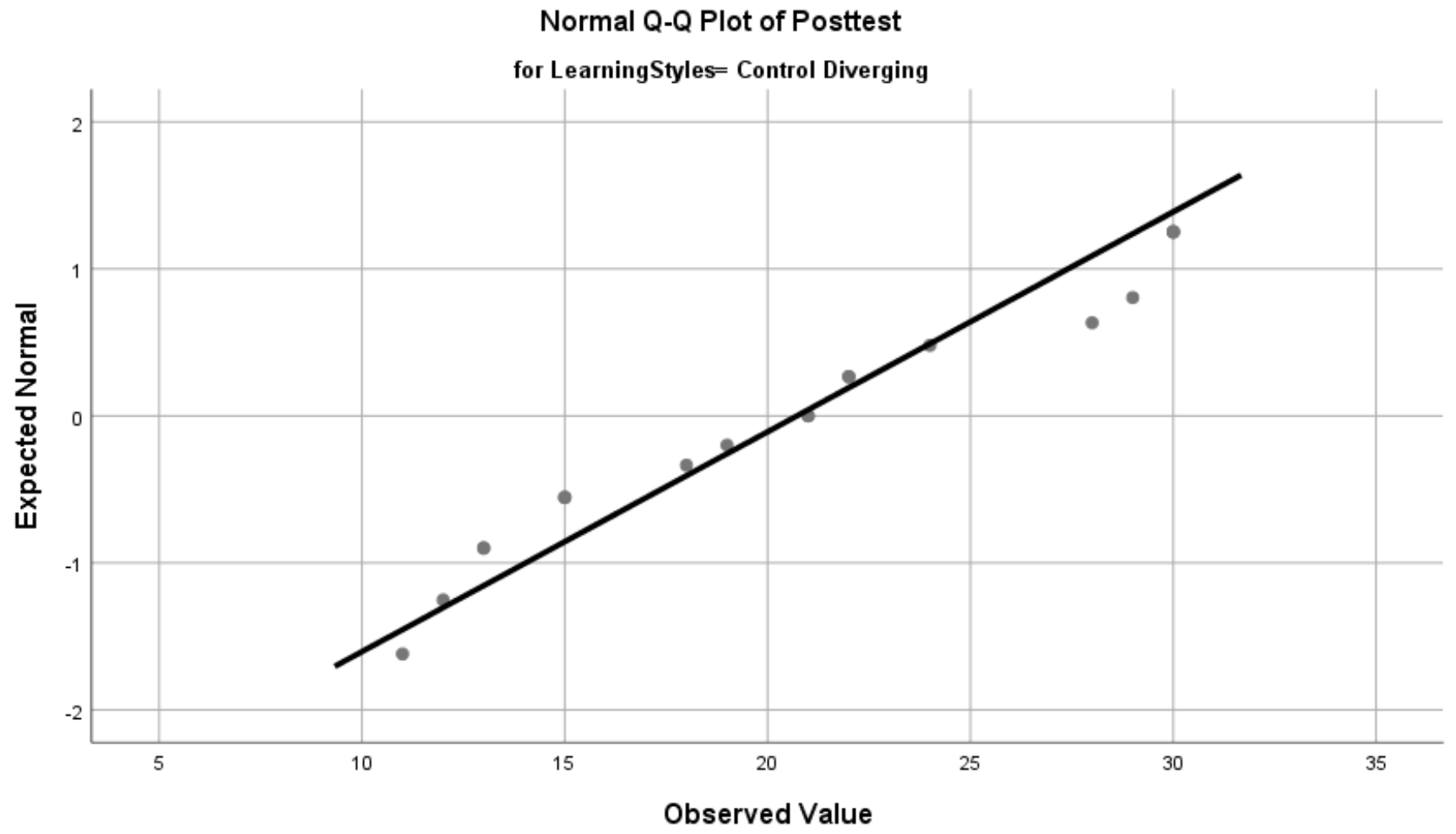

Figure 5

Q-Q Scatterplot Testing Normality for 4MAT

Page $16 / 23$ 


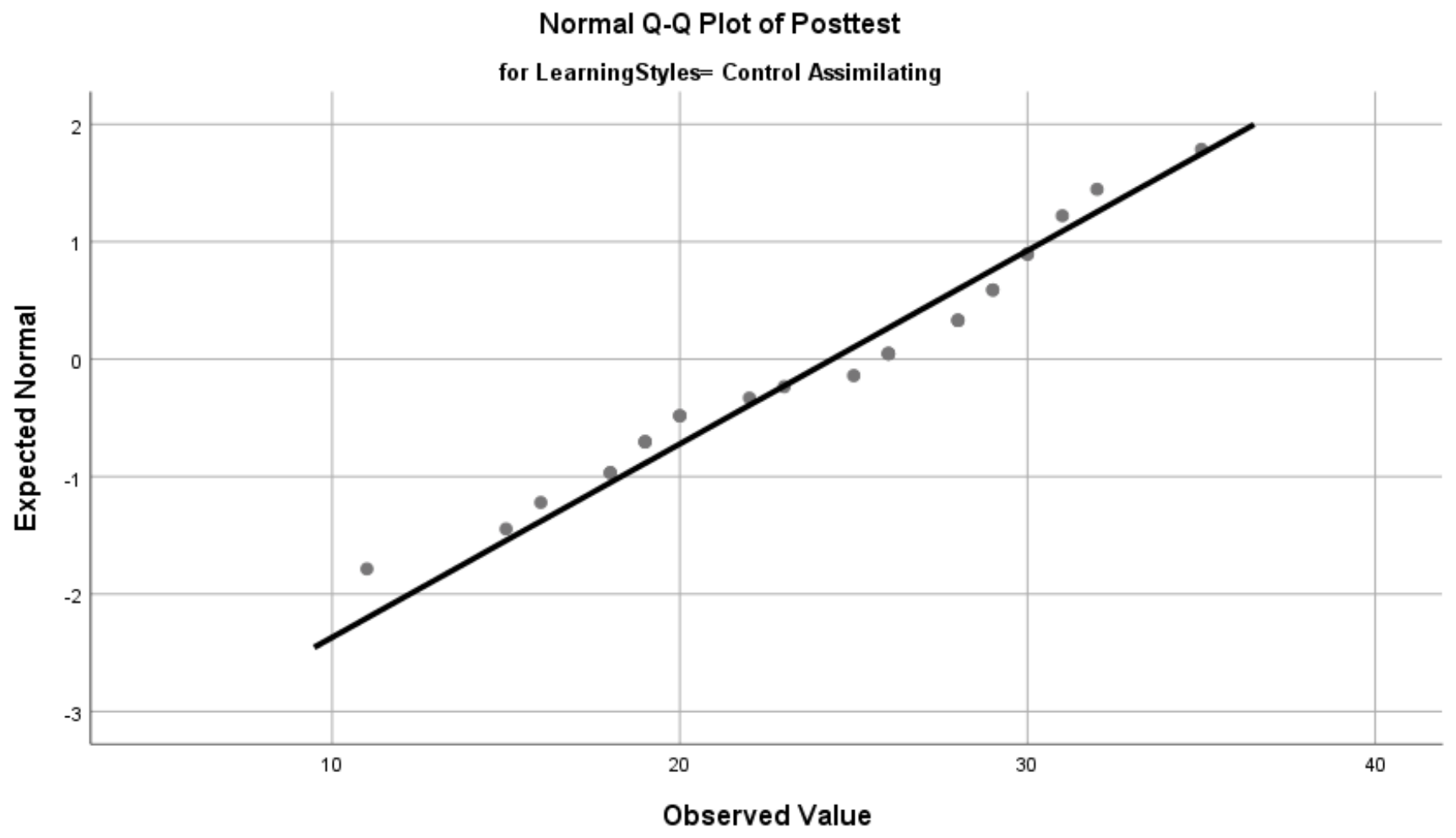

Figure 6

Q-Q Scatterplot Testing Normality for 4MAT

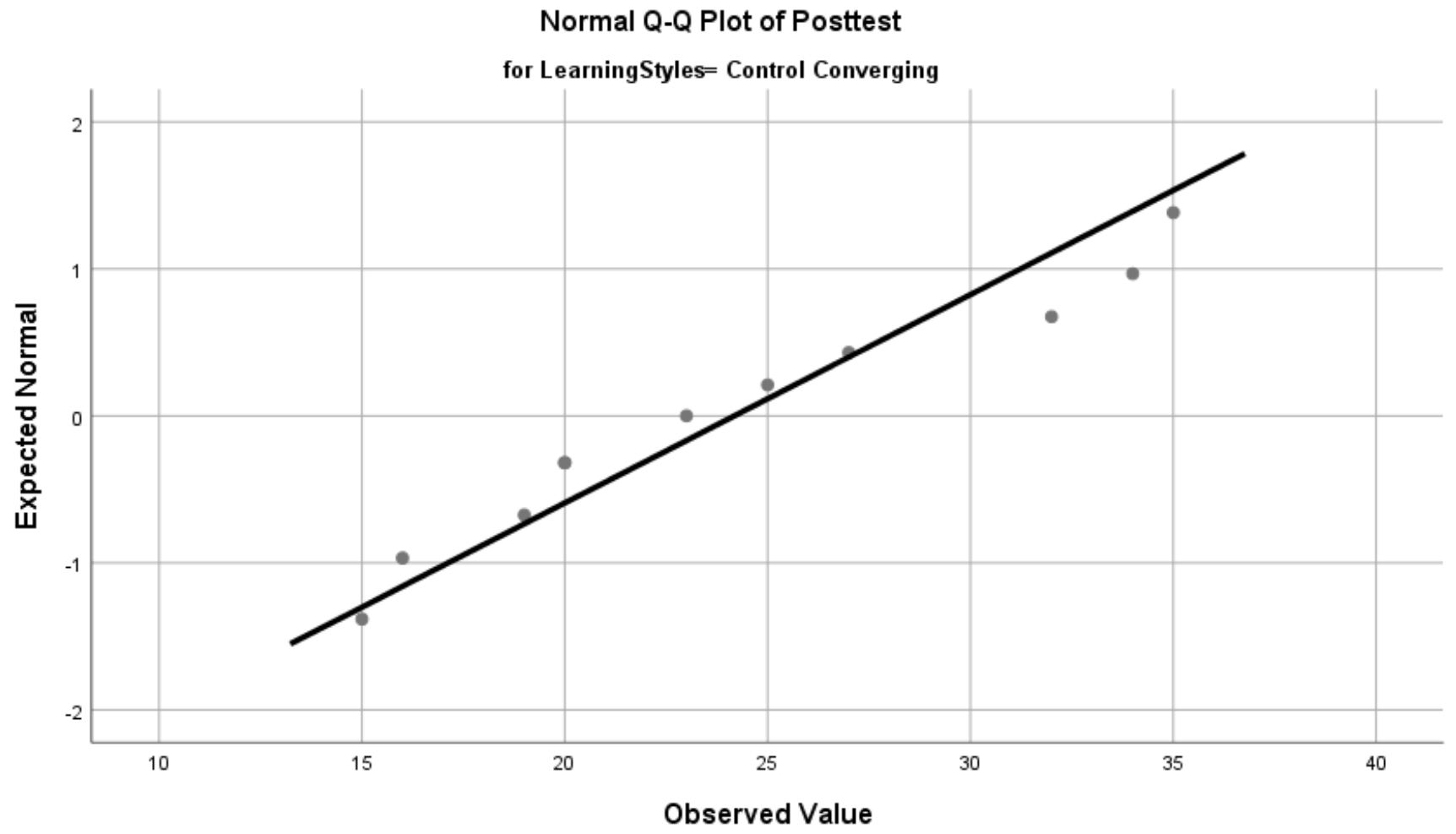

Figure 7

Q-Q Scatterplot Testing Normality for 4MAT

Page $17 / 23$ 


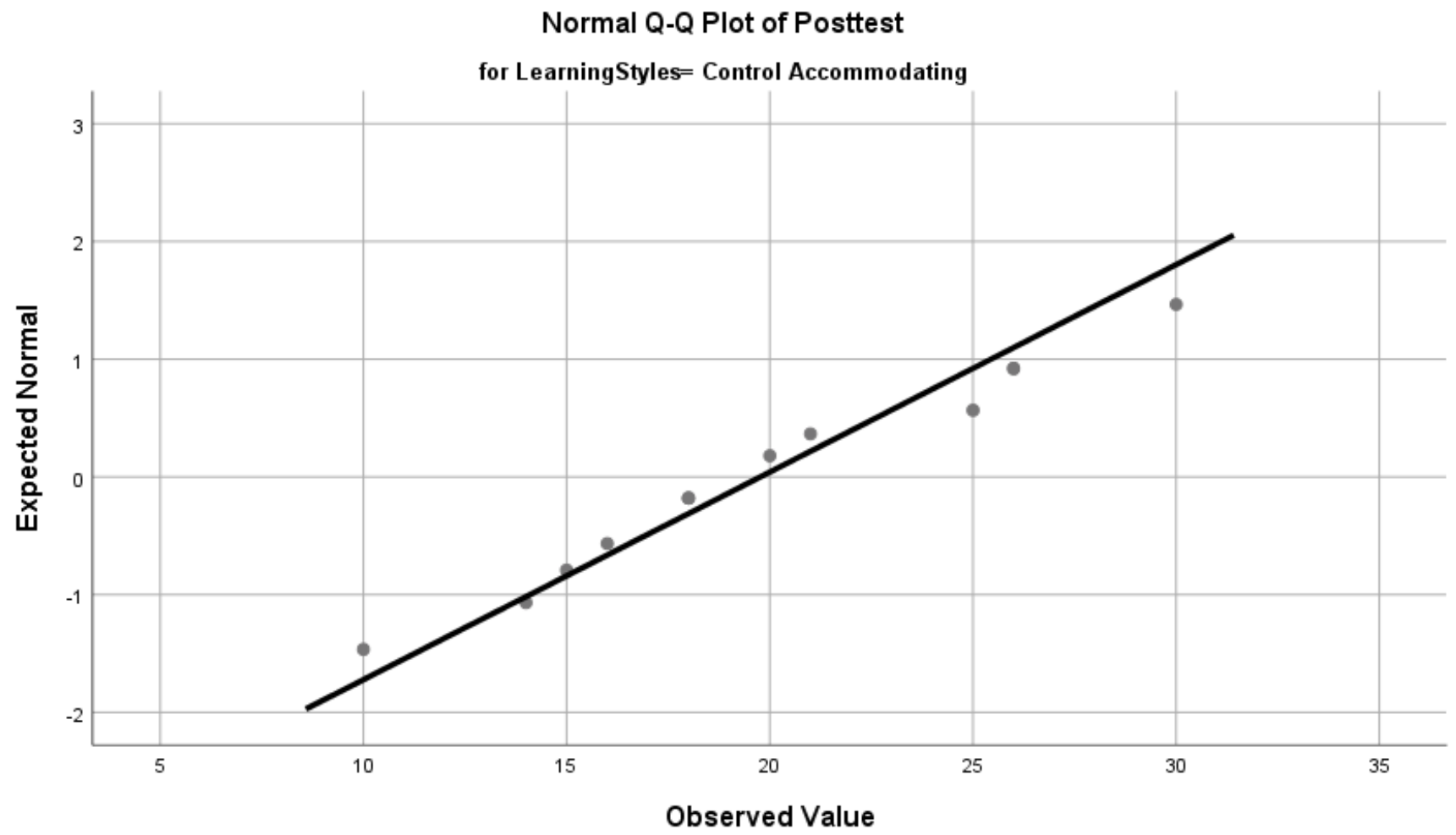

Figure 8

Q-Q Scatterplot Testing Normality for 4MAT

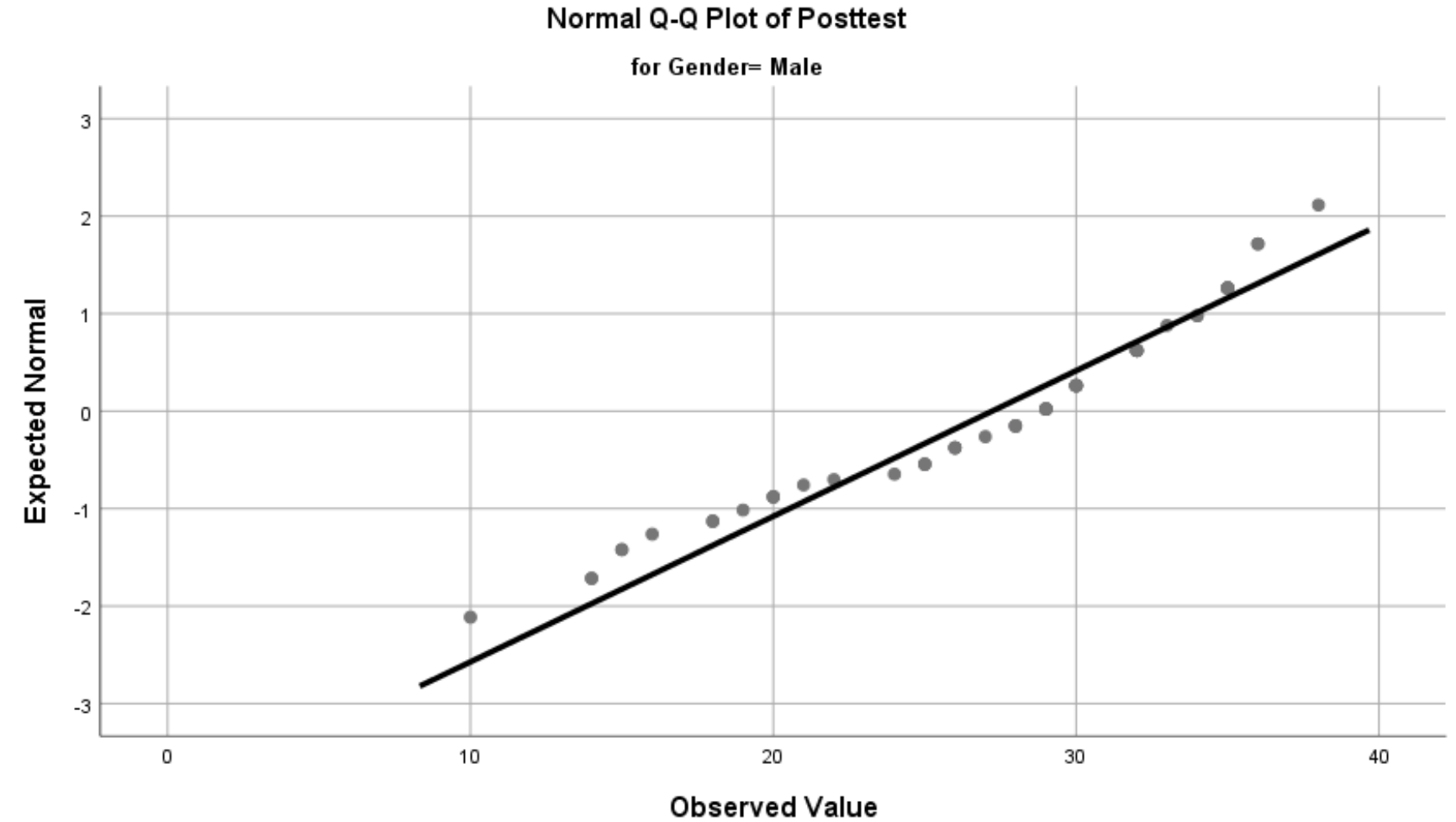

Figure 9

Q-Q Scatterplot Testing Normality for Male 


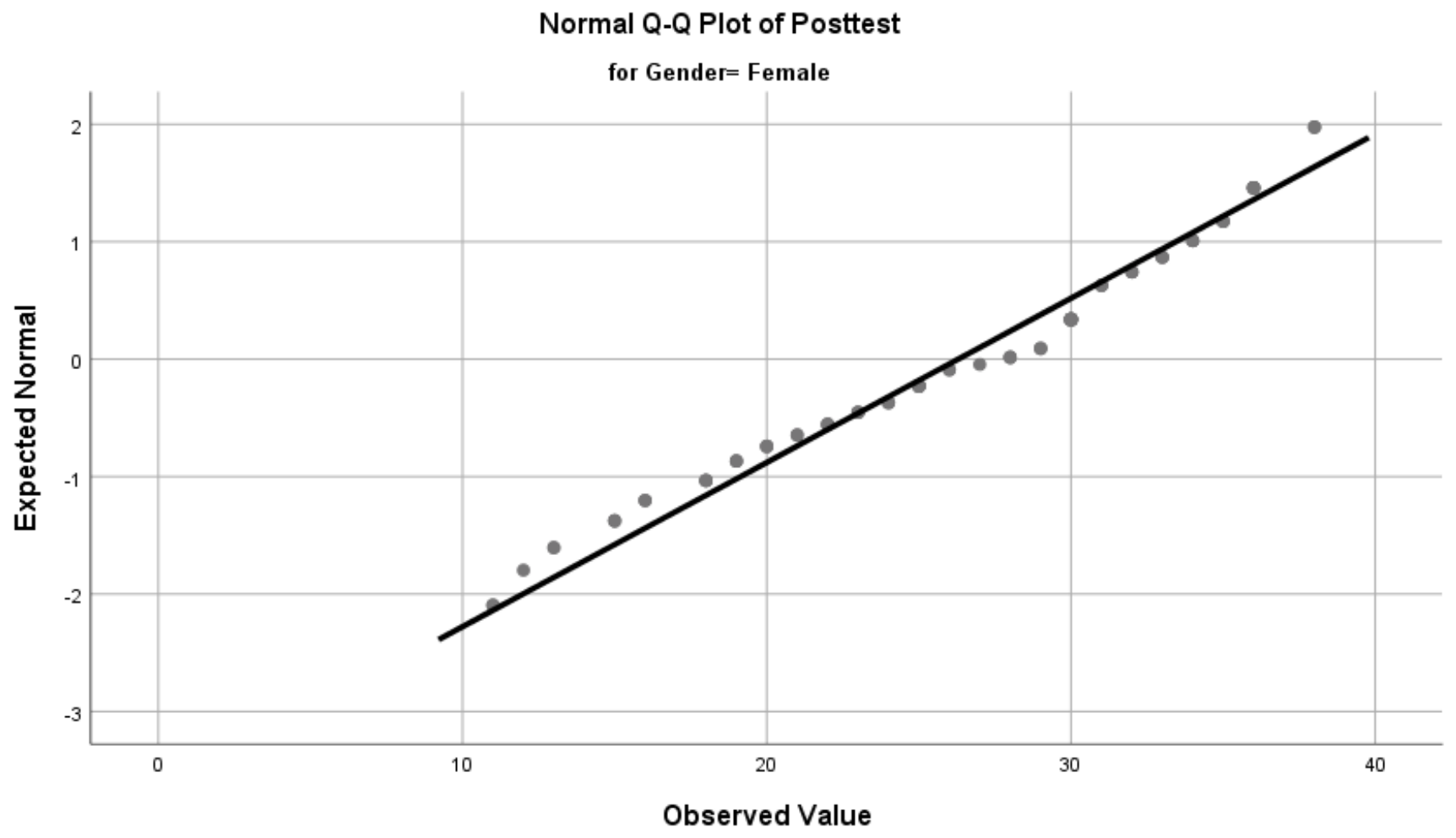

Figure 10

Q-Q Scatterplot Testing Normality for Female

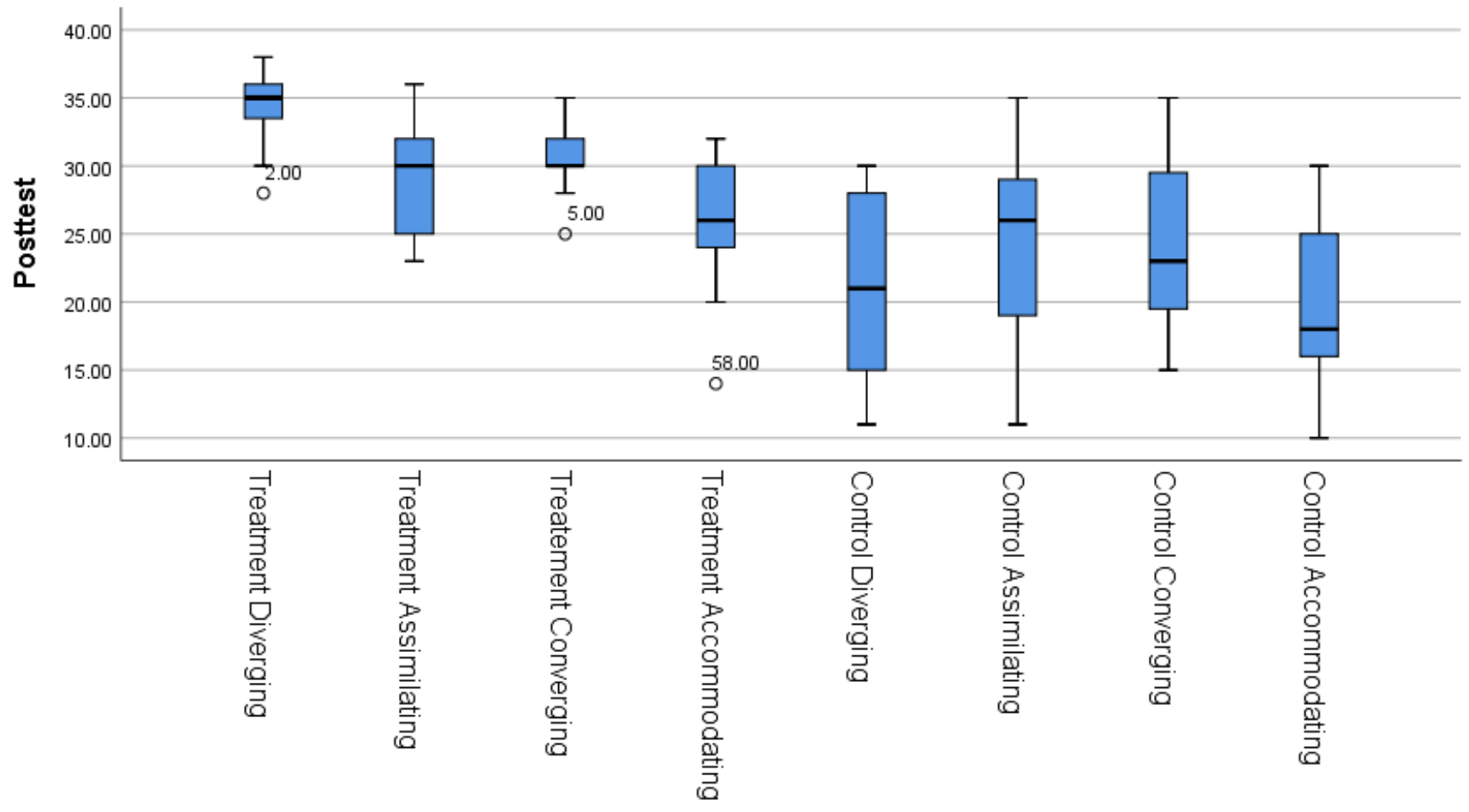

LearningStyles

Figure 11

Box Plot Testing for Outliers

Page $19 / 23$ 


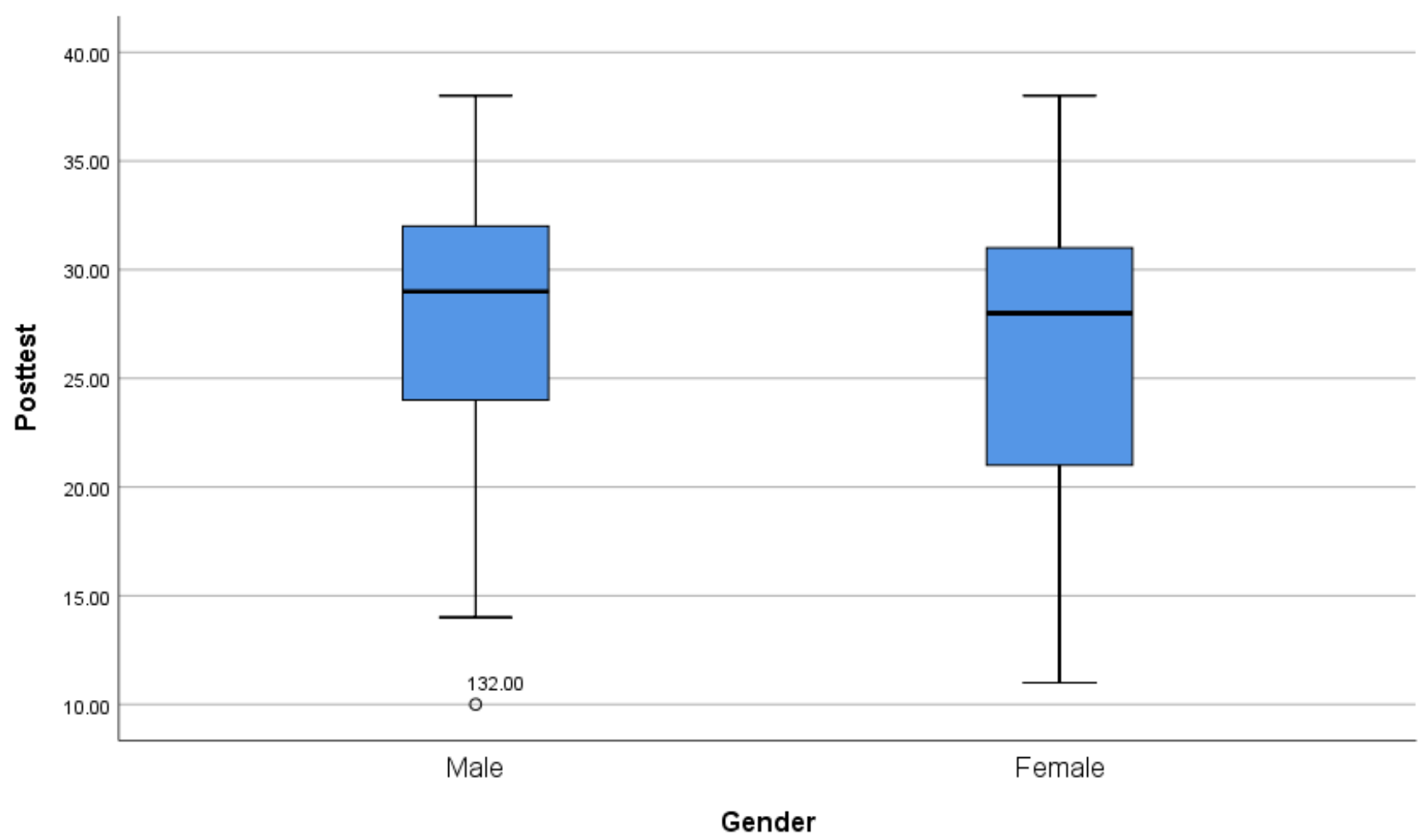

Figure 12

Box Plot Testing for Outliers

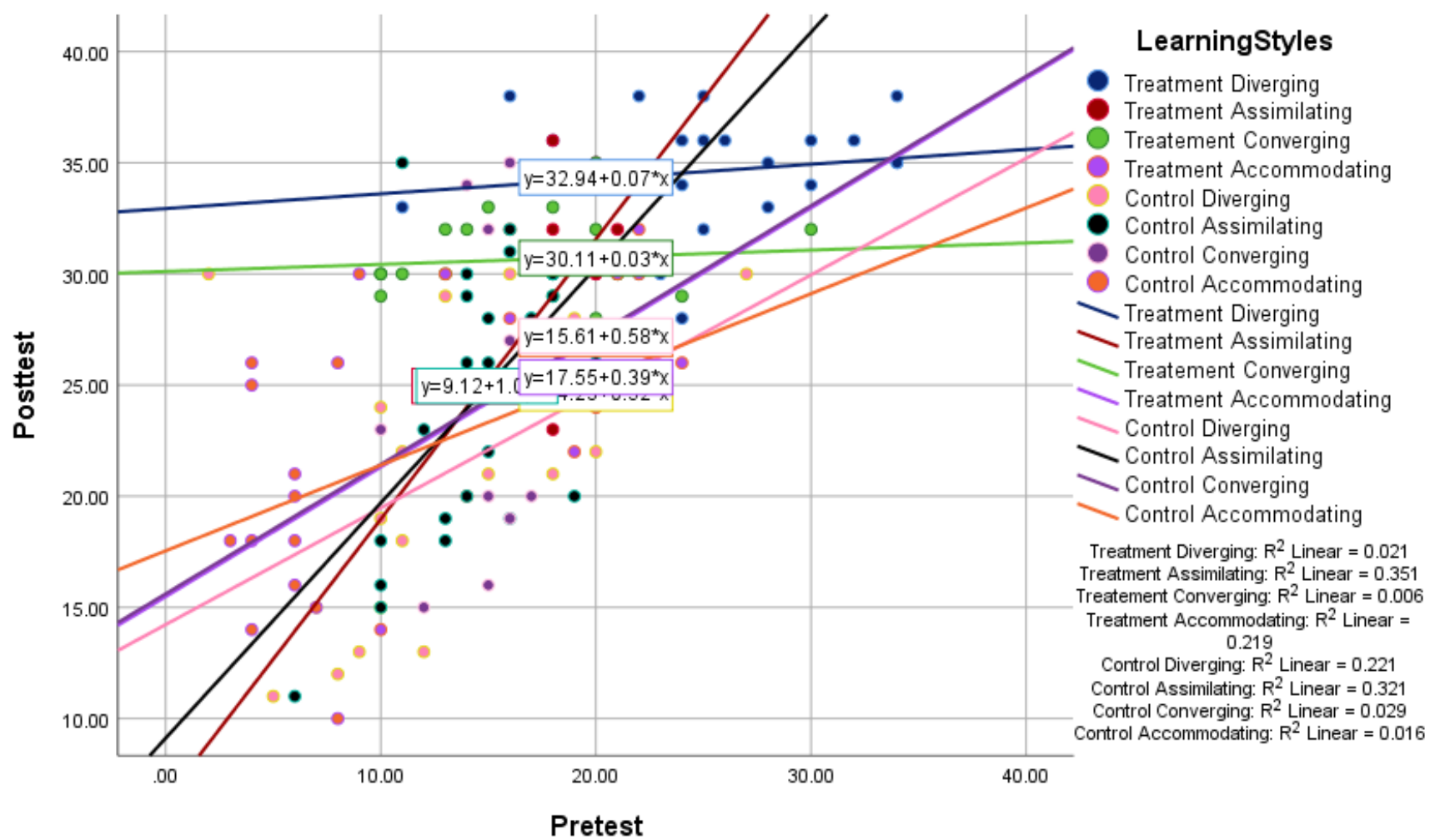

Figure 13

Linear Relationship between Dependent and Covariate by Each Level of the Independent Variable 


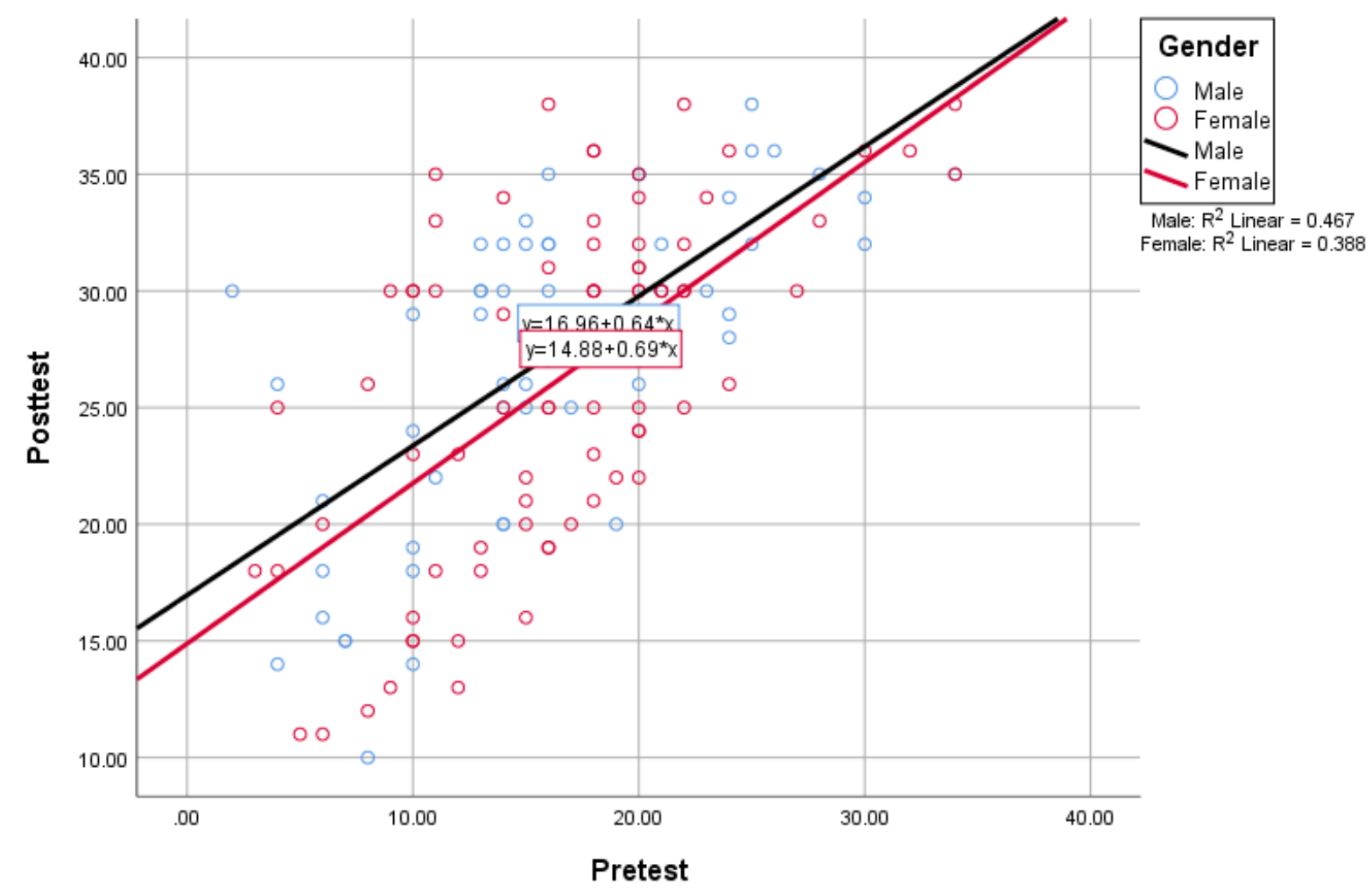

Figure 14

Linear Relationship between Dependent and Covariate by Each Level of the Independent Variable

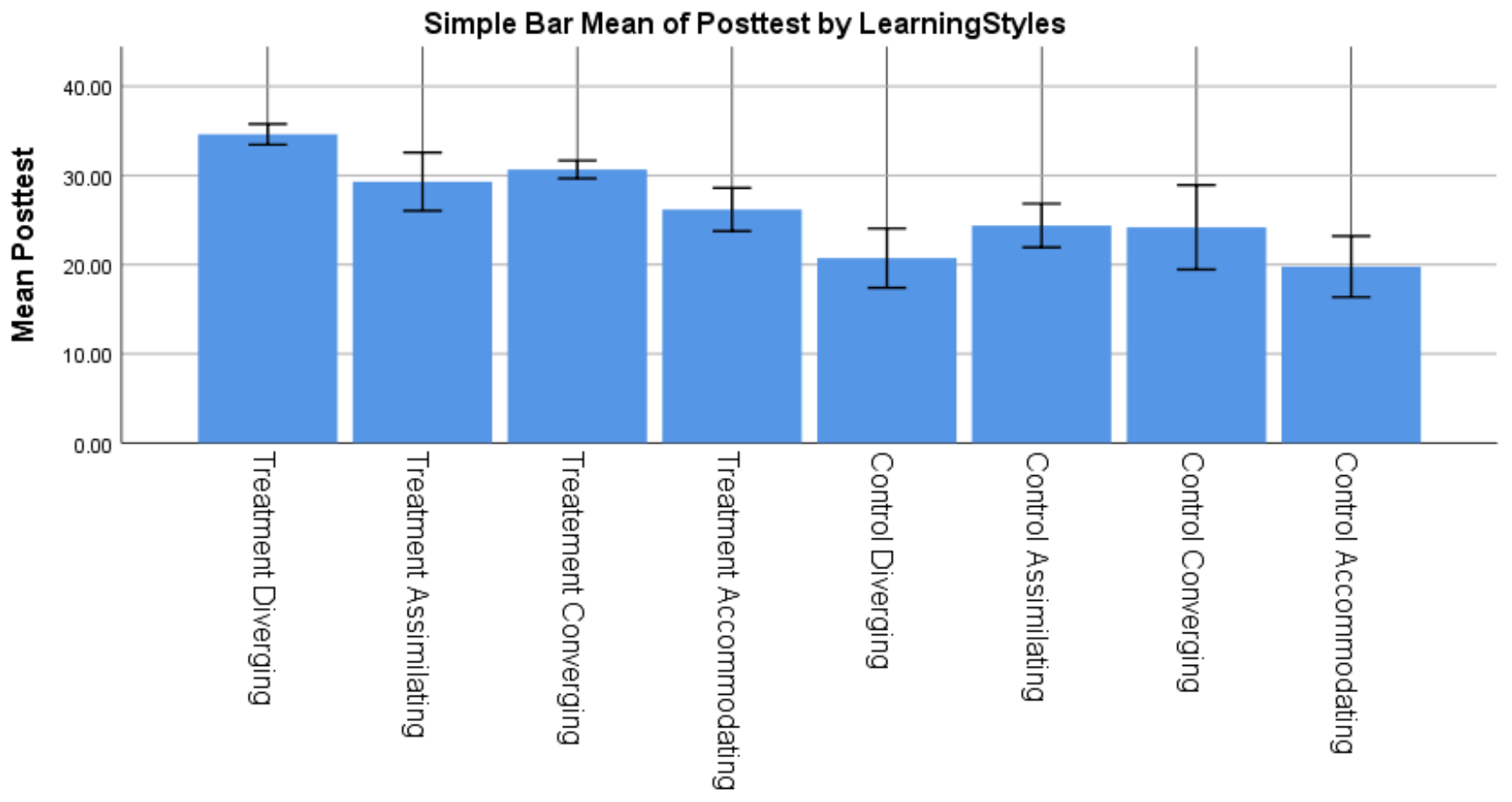

\section{LearningStyles}

Error Bars: $95 \% \mathrm{Cl}$

Figure 15

Simple Bar Mean of Posttest by Learning Styles 


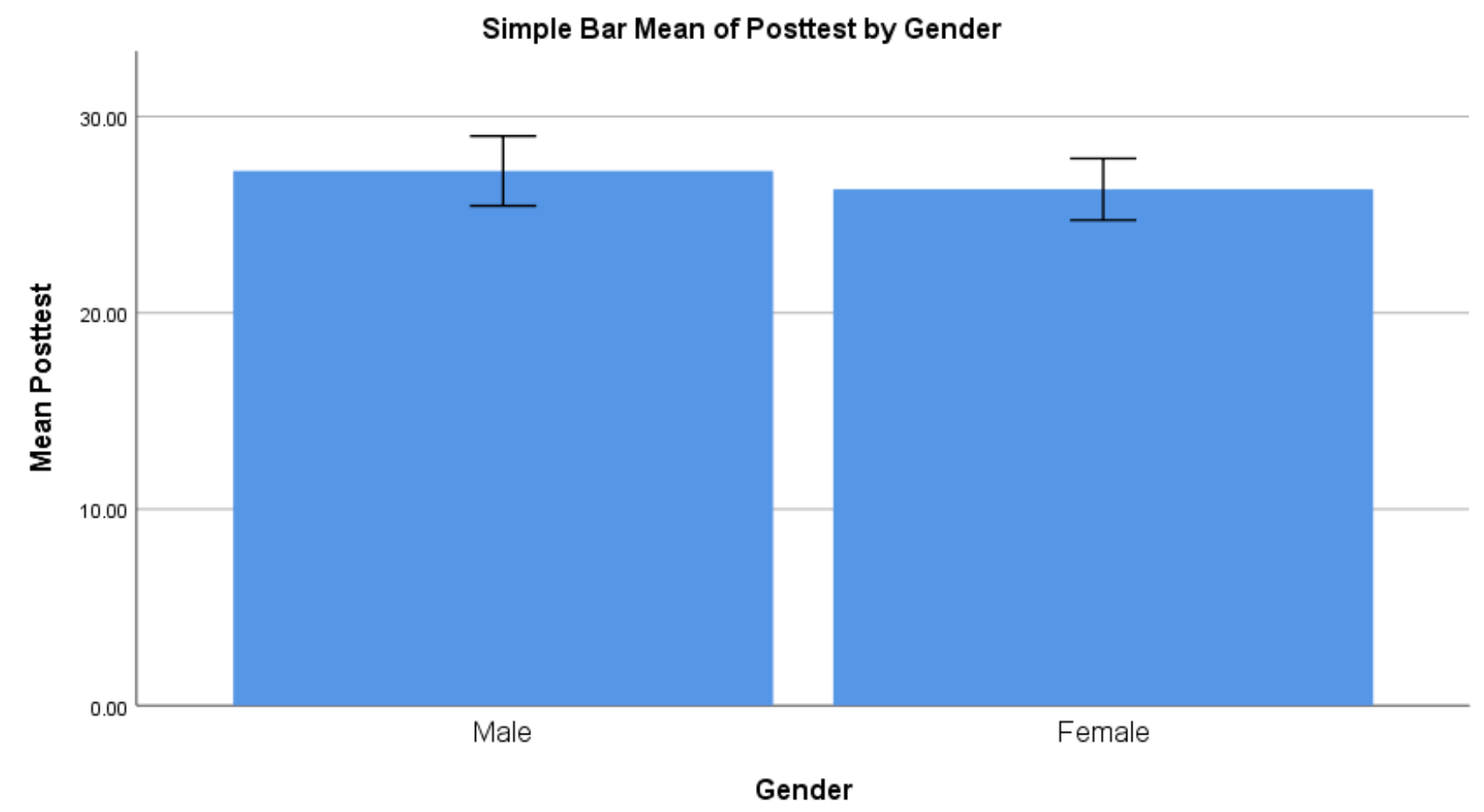

Error Bars: $95 \% \mathrm{Cl}$

\section{Figure 16}

Simple Bar Mean of Posttest by Gender

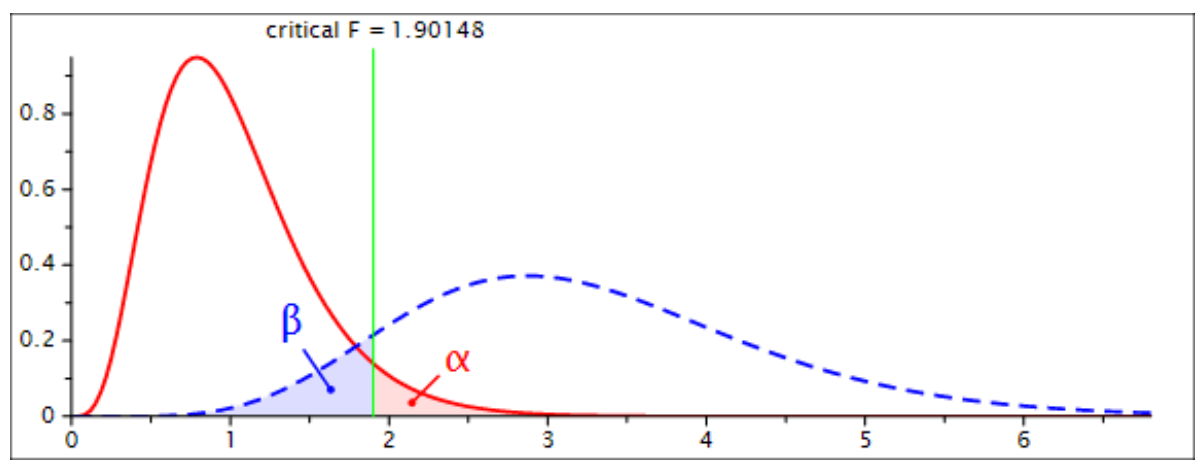

\section{Figure 17}

Power Analysis for calculation of sample size 


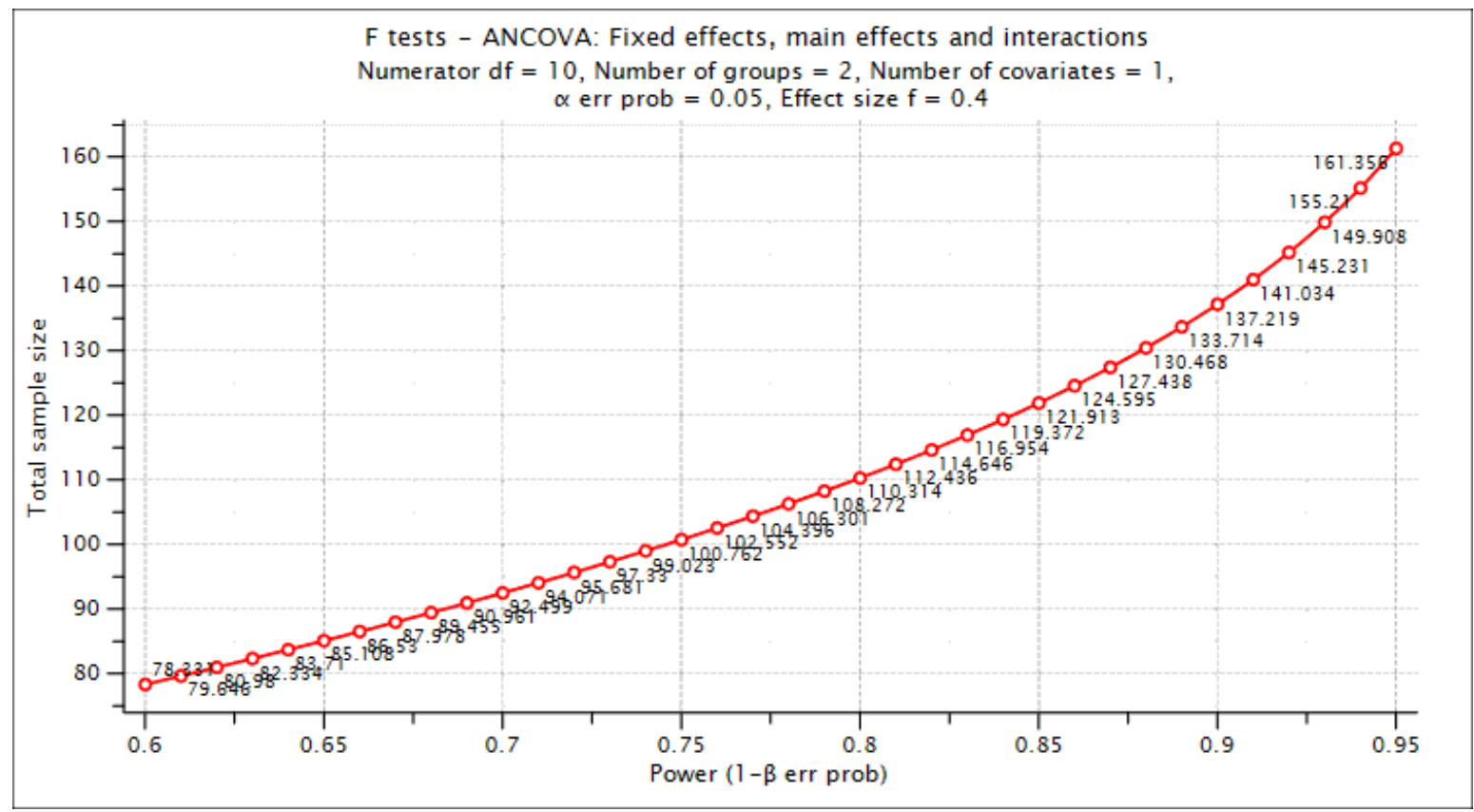

Figure 18

Power Analysis for calculation of sample size

\section{Supplementary Files}

This is a list of supplementary files associated with this preprint. Click to download.

- APPENDIXA.docx 